\title{
Efficiency and adaptability of the benthic methane filter at Quepos Slide cold seeps, offshore of Costa Rica
}

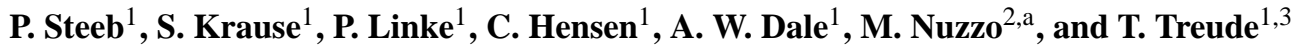 \\ ${ }^{1}$ GEOMAR Helmholtz Centre for Ocean Research Kiel, Wischhofstrasse 1-3, 24148 Kiel, Germany \\ 22IPMA, Marine Geology Department \& Institute Dom Luiz, University of Lisbon, Lisbon, Portugal \\ ${ }^{3}$ Present address: University of California, Los Angeles, Department of Earth Planetary \& Space Sciences and Department of \\ Atmospheric and Oceanic Sciences, Los Angeles, CA, USA \\ anow at: Integrated Geochemical Interpretation Ltd, Bideford, UK
}

Correspondence to: P. Steeb (psteeb@geomar.de); T. Treude (ttreude@g.ucla.edu)

Received: 20 September 2014 - Published in Biogeosciences Discuss.: 25 November 2014

Revised: 31 August 2015 - Accepted: 24 September 2015 - Published: 25 November 2015

\begin{abstract}
Large amounts of methane are delivered by fluids through the erosive forearc of the convergent margin offshore of Costa Rica and lead to the formation of cold seeps at the sediment surface. Besides mud extrusion, numerous cold seeps are created by landslides induced by seamount subduction or fluid migration along major faults. Most of the dissolved methane migrating through the sediments of cold seeps is oxidized within the benthic microbial methane filter by anaerobic oxidation of methane (AOM). Measurements of AOM and sulfate reduction as well as numerical modeling of porewater profiles revealed a highly active and efficient benthic methane filter at the Quepos Slide site, a landslide on the continental slope between the Nicoya and Osa Peninsula. Integrated areal rates of AOM ranged from 12.9 \pm 6.0 to $45.2 \pm 11.5 \mathrm{mmol} \mathrm{m}^{-2} \mathrm{~d}^{-1}$, with only 1 to $2.5 \%$ of the upward methane flux being released into the water column.

Additionally, two parallel sediment cores from Quepos Slide were used for in vitro experiments in a recently developed sediment-flow-through (SLOT) system to simulate an increased fluid and methane flux from the bottom of the sediment core. The benthic methane filter revealed a high adaptability whereby the methane oxidation efficiency responded to the increased fluid flow within ca. $170 \mathrm{~d}$. To our knowledge, this study provides the first estimation of the natural biogeochemical response of seep sediments to changes in fluid flow.
\end{abstract}

\section{Introduction}

Subduction zones represent large-scale systems of sediment and element recycling. Organic carbon accumulation at continental margins can lead to the formation of large methane reservoirs through its biological or thermogenic breakdown (Judd et al., 2002; Schmidt et al., 2005; Hensen and Wallmann, 2005; Crutchley et al., 2014). Produced methane gas may be transported upwards in solution by molecular diffusion or by ascending fluids, mobilized by, for example, sediment compaction or clay mineral dehydration (Hensen et al., 2004; Tryon et al., 2010; Crutchley et al., 2014). When the fluids are highly enriched in hydrocarbon gases, gas hydrates may precipitate depending on the pressure-temperature conditions (Hensen and Wallmann, 2005). Gas hydrates sometimes block fluid pathways (Tryon et al., 2002; Minami et al., 2012) and change the composition of fluids flowing through the gas hydrate stability zone (GHSZ). Alternatively, dissociating gas hydrates can act as additional sources of methane and fluids (Kvenvolden, 2002) or dilute fluids when they dissolve (Hesse et al., 2000; Hensen et al., 2004).

The migration of methane-charged fluids towards the sediment-water interface creates so-called "cold seeps" (Judd et al., 2002; Suess, 2010). Within the surface sediment, the majority of the methane is consumed by the anaerobic oxidation of methane (AOM) (Hinrichs and Boetius, 2002; Knittel and Boetius, 2009). AOM is coupled to sulfate reduction and produces dissolved bicarbonate and sulfide. The reaction is mediated by a consortium of anaero- 
bic methanotrophic archaea (commonly known as anaerobic methanotrophs, ANME) and sulfate-reducing bacteria (SRB) (Boetius et al., 2000). Recent studies propose that some ANME can reduce sulfate without the aid of SRB (Milucka et al., 2012). Additionally, the use of other electron acceptors such as Mn, Fe (Beal et al., 2009), or nitrate (Ettwig et al., 2010) is also possible. However, sulfate is the most abundant electron acceptor in seawater and AOM coupled to sulfate reduction is, to our knowledge, by far the most important anaerobic pathway for methane oxidation in marine settings (Reeburgh, 2007).

The sediment zone, in which methane and sulfate concentrations overlap, is termed the sulfate-methane transition zone (SMTZ). The depth of the SMTZ is dependent on (1) sulfate depletion resulting from organic matter degradation (Borowski et al., 1999); (2) sulfate supply by diffusion, bioirrigation and sulfide re-oxidation reactions (Dale et al., 2009); (3) the flux of methane from below the SMTZ (Borowski et al., 1996); and (4) the advective fluid flow rate (Treude et al., 2003; Orcutt et al., 2011). At continental margins, the SMTZ can sometimes be located several hundreds of meters below the seafloor (mbsf) (Borowski et al., 1999). In coastal sediments, sulfate is consumed rapidly via organoclastic sulfate reduction fueled by an enhanced supply of organic matter, and, subsequently, the SMTZ is often located closer to the sediment-water interface compared to sediments in greater water depths (Hinrichs and Boetius, 2002). At seepage sites, upwards advective flow of methane-rich fluid pushes the SMTZ closer to the surface, occasionally to only a few centimeters below the seafloor (cmbsf) (Treude et al., 2003; Niemann et al., 2006; Krause et al., 2014). At the center of the Håkon Mosby mud volcano, advective fluid flow is so high that it inhibits sulfate penetration into the sediment (de Beer et al., 2006; Niemann et al., 2006), resulting in the absence of a SMTZ. The depth of the SMTZ determines which chemolithotrophic seep organisms have access to the produced sulfide. The prevailing communities serve as indicators of seepage intensity. Sites covered by mats of sulfur bacteria (e.g., Beggiatoa) exhibit a very shallow SMTZ (a few centimeters) compared to clam sites (e.g., Calyptogena) with SMTZ depth of $\sim 5-10 \mathrm{~cm}$, or even deeper SMTZ in tubeworm or Solemya habitats (Sahling et al., 2002; Levin, 2003; Treude et al., 2003; Mau et al., 2006; Fischer et al., 2012).

In the present study, we compared data from field measurements, numerical modeling, and laboratory flow-through experiments of samples taken at Quepos Slide, a submarine landslide on the Pacific coast off Costa Rica (Bohrmann et al., 2002; Karaca et al., 2012) in order to investigate the effect of fluid flow on methane consumption and emission. The numerical model was developed to compare with direct measurements of $\mathrm{AOM}$ and sulfate reduction rates and to determine the magnitude of the fluid advection velocity. In laboratory experiments, undisturbed sediments from Quepos Slide were exposed to different flow conditions, to investi- gate the development of the SMTZ and the response of the benthic microbial methane filter. For this objective, we used a newly developed sediment-flow-through system, referred to as SLOT (Steeb et al., 2014), which mimics natural fluid flow regimes. It was the overall goal of this study to better understand mechanisms controlling the efficiency of this methane filter, which plays a major role in reducing greenhouse gas emissions from the ocean into the atmosphere (Reeburgh, 2007).

\section{Geological setting}

At the Mid-American Trench, the Cocos Plate in the north and Nazca Plate in the south are subducted below the Caribbean Plate at a velocity of $8.8 \mathrm{~cm} \mathrm{yr}^{-1}$ (Syracuse and Abers, 2006). Here, seep features like mud volcanoes, mud diapirs, and pockmarks are very abundant. More than 100 seeps localities have been identified at the central Costa Rican Pacific Trench, on average one seep every $4 \mathrm{~km}$ (Sahling et al., 2008). Recent high-resolution mapping has revealed even greater seep density in this region (Kluesner et al., 2013). Between the Nicoya (north) and Osa Peninsula (south), seamounts from the Nasca Plate are subducted (Ranero and von Huene, 2000), resulting in slope failures and landslides or scarps (e.g., Jaco Scarp, BGR landslide, GEOMAR landslide; Harders et al., 2011; Ranero et al., 2008). Landslide-induced seeps are created by opening new structural and stratigraphical fluid pathways (Ranero et al., 2008; Mau et al., 2012) or by gas hydrate dissociation resulting from altered pressure and temperature conditions.

Fluids and related methane fluxes can vary both spatially and temporally as well as in origin, composition, and flow velocity. Temporal variations can be caused by gas hydrate formation and dissociation (Hesse et al., 2000; Tryon et al., 2002; Hensen et al., 2004; Minami et al., 2012) or triggered by earthquakes, which are frequent in this active subduction zone (Tryon et al., 2002; Hensen et al., 2004; Aiello, 2005; Henrys et al., 2006; Mau et al., 2007; Fischer et al., 2013).

Well-known examples exhibiting such dynamics are the twin mounds "Mound 11" and "Mound 12", located at $1000 \mathrm{~m}$ water depth, halfway between the Nicoya and Osa Peninsula. Both mounds are located at the same fault zone, although they differ in fluid flow advection intensity (Hensen et al., 2004; Linke et al., 2005; Karaca et al., 2010; Krause et al., 2014), fluid origin (Hensen et al., 2004; Han et al., 2004; Schmidt et al., 2005), and microbial activity (Krause et al., 2014). In the last $50 \mathrm{kyr}$ both mounds have displayed individual active phases interrupted by phases of inactivity (Kutterolf et al., 2008). In contrast to this long-term variability, Füri et al. (2010) observed a 2-month seepage event at Mound 11 with flow rates that varied 4-fold (from 5 to $20 \mathrm{~cm} \mathrm{yr}^{-1}$ ). Events like this affect the efficiency of the benthic microbial methane filter and result in increased methane concentrations in the water column. Slow adaptation to increased methane supply may explain elevated methane con- 
centrations in the water column offshore of Costa Rica found by Mau et al. (2007) in 2003, presumably caused by an earthquake earlier that year.

The research area of the present study, the Quepos Slide, is located south of the twin Mounds 11 and 12. This landslide is approximately $9.5 \mathrm{~km}$ wide and $8 \mathrm{~km}$ long (Harders, 2011). The translational slide has a headwall $160 \mathrm{~m}$ in height and the slide head is located at $\sim 400 \mathrm{~m}$ water depth in the eastern Pacific oxygen minimum zone (OMZ; between 250 and $550 \mathrm{~m}$ water depth; Bohrmann et al., 2002). Four tongues of the landslide can be identified, reaching down to $\sim 800$ water depth, indicating three subsequent events following the initial slide (Bohrmann et al., 2002; Harders et al., 2011). The Quepos Slide was most likely caused by seamount subduction (Harders et al., 2011). Along the toe, fluids and gas can migrate from hydrates inside the GHSZ. Chemosynthetic organisms are abundant, with bacterial mats present throughout, while authigenic carbonates and clams can be found at deeper areas and at the toe of the slide (Bohrmann et al., 2002). Directly below the headwall, the sediments are covered by sulfur bacteria mats (Bohrmann et al., 2002; Sahling et al., 2008; Karaca et al., 2012). Empirical models show that vertical fluid flow at Quepos Slide varies between 1 and $40 \mathrm{~cm} \mathrm{yr}^{-1}$ and AOM rates vary between 1.5 and $42.1 \mathrm{mmol} \mathrm{m}^{-2} \mathrm{~d}^{-1}$ (Karaca et al., 2012). According to that model, $53 \%\left(\sim 316 \times 10^{3} \mathrm{~mol} \mathrm{yr}^{-1}\right)$ of the dissolved methane is oxidized by the highly active benthic microbial methane filter, while $47 \%\left(280 \times 10^{3} \mathrm{~mol} \mathrm{yr}^{-1}\right)$ is released into the water column. Elevated methane concentrations of $72 \mathrm{nmol} \mathrm{L}^{-1}$ were observed in the seawater directly above the slide head (Bohrmann et al., 2002).

\section{Methods}

Surface sediments from Quepos Slide were obtained by a video-guided multicorer (TV-MUC) during the GEOMAR research cruise SO206 in June 2010 on the German research vessel SONNE. Two sites (SO206-29 MUC, SO20631 MUC) from the headwall of Quepos Slide, both covered by sulfur bacteria mats, were sampled (Table 1). All subsampling procedures were performed onboard at $4{ }^{\circ} \mathrm{C}$ immediately after obtaining the sediments. Three replicate cores (inner diameter $10 \mathrm{~cm}$ ) of each TV-MUC were used for (1) porewater analyses, (2) ex situ AOM and sulfate reduction rate assays, and (3) methane concentration determination. Additionally, two replicate cores of SO206-31 (MUC) were subsampled for laboratory experiments (SLOT system; see below).

\subsection{Porewater measurement (ex situ)}

Porewater of the ex situ samples was extracted by a pressurefiltration system and filtered (argon 3-4 bar, $0.2 \mu \mathrm{m}$ regenerated cellulose filters; Krause et al., 2014). Total alkalin-
Table 1. Sampling sites of the Quepos Slide and the SMTZ depth in centimeters below seafloor (cmbsf).

\begin{tabular}{lllrr}
\hline Station & $\begin{array}{l}\text { Latitude } \\
(\mathrm{N})\end{array}$ & $\begin{array}{l}\text { Longitude } \\
(\mathrm{W})\end{array}$ & $\begin{array}{r}\text { Water depth } \\
(\mathrm{m})\end{array}$ & $\begin{array}{r}\text { Depth of SMTZ } \\
(\mathrm{cmbs})\end{array}$ \\
\hline SO206-29 (MUC) & $8^{\circ} 51.29^{\prime}$ & $84^{\circ} 12.60^{\prime}$ & 402 & $12.5-22.5$ \\
SO206-31 (MUC) & $8^{\circ} 51.12^{\prime}$ & $84^{\circ} 13.06^{\prime}$ & 399 & $5.0-15.0$ \\
\hline
\end{tabular}

ity (TA) was analyzed onboard via titration (Ivanenkov and Lyakhin, 1978). Sulfide was determined photometrically using the methylene blue method (Cline, 1969). Subsamples for the determination of sulfate, chloride, and bromide were frozen and analyzed onshore by ion chromatography (Compact IC 761). Further porewater sampling and analytical procedures are described in detail by Krause et al. (2014).

\subsection{Methane (ex situ)}

For methane determination, $10 \mathrm{~cm}^{3}$ of sediment was transferred to $30 \mathrm{~mL}$ glass vials filled with $10 \mathrm{~mL}$ of $10 \% \mathrm{KCl}$ for poisoning and headspace equilibration. The methane concentration was determined onboard by a gas chromatograph coupled to a flame ionization detector (GC-FID) using a Shimadzu GC14A instrument fitted with a Restek Rt ${ }^{\circledR}$ Alumina Bond/ $\mathrm{KCl}$ capillary column $(50 \mathrm{~m}, 0.53 \mathrm{~mm}$ ID) operated at $60{ }^{\circ} \mathrm{C} . \mathrm{N}_{2}$ was used as a carrier gas.

\subsection{Microbial rate measurement (ex situ)}

Ex situ turnover rates of sulfate reduction and AOM were determined with radiotracer techniques. For both sulfate reduction and $\mathrm{AOM}$, three replicate polycarbonate tubes (26 mm inner diameter, $250 \mathrm{~mm}$ length) were subsampled from one TV-MUC core and incubated by whole core incubation (Jørgensen, 1978). Additional bulk sediment was sampled to produce controls. Fifteen microliters of ${ }^{14} \mathrm{CH}_{4}$ (1-2 kBq dissolved in anoxic, sterile water; specific activity $\left.22.28 \mathrm{GBq} \mathrm{mmol}^{-1}\right)$ and $6 \mu \mathrm{L}$ of ${ }^{35} \mathrm{SO}_{4}^{2-}(200 \mathrm{kBq}$ dissolved in water; specific activity $37 \mathrm{TBq} \mathrm{mmol}^{-1}$ ) were injected into the AOM and sulfate reduction cores, respectively, at a vertical resolution of $1 \mathrm{~cm}$; the cores were then incubated for $24 \mathrm{~h}$ in the dark at in situ temperature $\left(8^{\circ} \mathrm{C}\right)$. After incubation, the sediment cores were sliced at $1 \mathrm{~cm}$ intervals and transferred to $20 \mathrm{~mL}$ of $\mathrm{NaOH}(2.5 \% \mathrm{w} / v, 40 \mathrm{~mL}$ glass vials with rubber stopper) for AOM, and $20 \mathrm{~mL}$ of zinc acetate $(20 \%$ $w / v, 50 \mathrm{~mL}$ plastic vials) for sulfate reduction determinations. Control samples (five each) were first transferred to the respective chemicals before tracer was added (see above). AOM was determined according to Treude et al. (2005) (GC and combustion) and Joye et al. (2004) $\left({ }^{14} \mathrm{CO}_{2}\right.$ trapping). Sulfate reduction was determined using the cold chromium distillation method after Kallmeyer et al. (2004). 


\subsection{Numerical model}

Porewater profiles were simulated using a one-dimensional transport reaction model, previously used and described by Krause et al. (2014), to determine the flow velocity of the fluid and the rate of AOM. Carbonate precipitation was implemented in the model (Krause et al., 2014) but was not used in the present study, since carbonate precipitation does not affect the efficiency of the microbial benthic methane filter within the studied timescales (several months to years). Because the sampling sites were located above the GHSZ (Wallmann et al., 2012), dissolved methane concentrations at the lower boundary were calculated from the equilibrium concentration with free gas (Tishchenko et al., 2005). Table 2 provides an overview of other boundary conditions as well as fitted, measured, and calculated parameters of the model.

\subsection{Sediment-flow-through system}

The response of the sediment to changes in fluid and methane fluxes was studied using a newly developed sediment-flowthrough (SLOT) system (Steeb et al., 2014) which mimics natural flow conditions with diffusive supply of sulfate at the sediment surface and advective methane supply at the bottom of the core. The system enables continuous monitoring of geochemical gradients inside the sediment as well as in the in- and outflow and allows the development of the geochemical gradients and SMTZ to be observed. The efficiency of the benthic microbial methane filter during the transient periods can be calculated from the measured input and output fluxes (see below). For the present study we focused only on AOM - i.e., all incubations were kept strictly anoxic, as AOM is the most important process for methane removal in the sediment. The system has limitations, as it is not pressurized and therefore does not generate methane concentrations found in situ. The main interest in using it was to study the response of AOM and the SMTZ to different fluid flow rates, which should always be kept in mind when interpreting the results. Please refer to Steeb et al. (2014) for more details on the method's advantages and disadvantages.

For SLOT experiments, two replicate multicorer cores from station SO206-31 (MUC) were subsampled with specific SLOT liners (inner diameter $6 \mathrm{~cm}$ ) (Steeb et al., 2014). Liners were closed with rubber stoppers, sealed with electrical tape, transported $\left(4^{\circ} \mathrm{C}\right)$ to the home laboratory and stored at $0^{\circ} \mathrm{C}$ in the dark until the experiment started (ca. $170 \mathrm{~d}$ after the MUC sampling). At GEOMAR, filters (glass fiber, Whatman GF/F) were applied at the bottom of the sediment core and at the lower and upper cap, as previously described (Steeb et al., 2014).

The following experimentations were conducted at $10^{\circ} \mathrm{C}$ (the in situ temperature was $8^{\circ} \mathrm{C}$ ). Two different seawater media were applied; one medium, resembling seawater, was amended to natural sulfate concentrations $\left(28 \mathrm{mmol} \mathrm{L}^{-1}\right)$. The added sulfate penetrated the surface sediment by diffu- sion, except for when porewater subsamples were taken with rhizons (see below), which temporarily facilitated a faster intrusion of sulfate-rich water from the supernatant and probably caused a smoothening of porewater profiles (Steeb et al., 2014). The other medium, resembling sulfate-free seepage fluid, carried dissolved methane $\left(965 \pm 180 \mu \mathrm{mol} \mathrm{L}^{-1}\right)$ upwards into the bottom of the core by advection. Both media were based on the sulfate reducer medium developed by Widdel and Bak (2006). In the "seepage" medium, $\mathrm{MgSO}_{4}$ was replaced by $\mathrm{MgCl}$. Both media were kept anoxic and contained resazurin as an oxygen indicator (Visser et al., 1990), with a $\mathrm{pH}$ adjusted to 7.5 and a salinity of 35 PSU. Bromide served as an inert tracer for the upward migration and was present only in the methane-enriched seepage medium $\left(800 \mu \mathrm{mol} \mathrm{L}^{-1}\right)$. Hence, the depth where bromide and sulfate concentrations overlapped was interpreted as the SMTZ. We therefore used the sulfate-bromide transition zone (SBTZ) as a proxy for the SMTZ and defined it as the zone with the steepest $\mathrm{SO}_{4}^{2-}$ and $\mathrm{Br}^{-}$gradients. The composition of the medium, as well as that of the gas headspace of the reservoirs, is summarized in Table 3.

SLOT experiments were performed with two sediment cores under different flow regimes (Table 4). One core was exposed to a relatively moderate advective fluid flow velocity $\left(10.6 \mathrm{~cm} \mathrm{yr}^{-1}\right)$, here further referred as the low-flow core (LFC), whereas the other core was exposed to a 10fold higher advective fluid flow velocity $\left(106.3 \mathrm{~cm} \mathrm{yr}^{-1}\right)$, further referred as the high-flow core (HFC). The moderate fluid flow velocities were on the same order as those determined by the numerical model (see Results). The high flow velocities were more than twice of those previously reported for Quepos Slide ( $40 \mathrm{~cm} \mathrm{yr}^{-1}$; Karaca et al., 2012) and were employed to observe the sediment response under extreme fluid flow. Similar or even higher (up to $200 \mathrm{~cm} \mathrm{yr}^{-1}$ ) advective flow velocities have been reported for seeps within the same region (Hensen et al., 2004; Linke et al., 2005; Karaca et al., 2010; Krause et al., 2014). The applied fluid flow velocities were strong enough to observe considerable changes within the time frame of 1 year yet weak enough to avoid sulfate penetration to less than $1 \mathrm{~cm}$.

In the initial preparation phase of the experiment $(40 \mathrm{~d})$, the outflow of the system was located at the bottom of the core and only methane-free seawater medium was pumped from top to bottom at a pump rate of $20 \mu \mathrm{L} \mathrm{min}^{-1}$. This procedure was applied to establish a homogeneous sulfate distribution and anoxic conditions throughout the entire sediment column without disturbing the sediment fabric, although some sediment compaction might occur. In the subsequent first experimental phase, the outflow was mounted at the top of the core and seawater medium was delivered to the overlying seawater at a pump rate of $20 \mu \mathrm{L} \mathrm{min}^{-1}$. From this point, sulfate was transported into the sediment core solely via diffusion, except for rhizon sampling (see above). From the bottom, the seepage medium was supplied at $0.5 \mu \mathrm{L} \mathrm{min}^{-1}$ (LFC) and $5 \mu \mathrm{L} \mathrm{min}^{-1}$ (HFC) with an average 
Table 2. Summary of input parameters used for the model simulations and major model results. For the SO206-31 (MUC) cores, two fits are provided, since the replicate core for porewater determinations (pw-fit) exhibited a lower fluid flow and deeper SMTZ than the core used for rate determinations (hf-fit), probably as a result of high fluid flow heterogeneity at the site (see discussion). For more model details, see Krause et al. (2014).

\begin{tabular}{|c|c|c|c|c|c|}
\hline Parameter & SO206-29 (MUC) & SO206-31 (MUC) & SO206-31 (MUC) & Unit & Parameter \\
\hline & & pw-fit & hf-fit & & source \\
\hline \multicolumn{6}{|l|}{ Model parameter values } \\
\hline Length of core & 32 & 44 & 44 & $\mathrm{~cm}$ & measured \\
\hline Length of simulated column & 80 & 80 & 50 & $\mathrm{~cm}$ & fitted \\
\hline Number of model layers & 160 & 200 & 200 & & set \\
\hline Temperature & 8 & 8 & 8 & ${ }^{\circ} \mathrm{C}$ & measured \\
\hline Salinity & 35 & 35 & 35 & PSU & measured \\
\hline Pressure & 41 & 41 & 41 & bar & measured \\
\hline Porosity at sediment surface & 0.95 & 0.93 & 0.93 & & measured \\
\hline Porosity at the base of the sediment core & 0.75 & 0.70 & 0.70 & & measured \\
\hline Porosity at infinity sediment depth & 0.74 & 0.70 & 0.70 & & fitted \\
\hline Attenuation coef. for porosity decrease with depth & 0.04 & 0.04 & 0.04 & $\mathrm{~cm}^{-1}$ & fitted \\
\hline Burial velocity at depth & 0.02 & 0.02 & 0.03 & $\mathrm{~cm} \mathrm{yr}^{-1}$ & fitted \\
\hline Fluid flow at the sediment-water interface & 7 & 5 & 29 & $\mathrm{~cm} \mathrm{yr}^{-1}$ & fitted \\
\hline Kinetic constant for AOM & 200000 & 25000 & 100000 & $\mathrm{~cm}^{3} \mathrm{mmol}^{-1} \mathrm{yr}^{-1}$ & fitted \\
\hline Kinetic constant for $\mathrm{CaCO}_{3}$ precipitation & 0 & 0 & 0 & $\mathrm{yr}^{-1}$ & fitted \\
\hline Density of dry solids in sediment & 2.5 & 2.5 & 2.5 & $\mathrm{~g} \mathrm{~cm}^{-3}$ & assumed \\
\hline Kinetic constant for sulfide removal from porewater & 0.02 & 0.1 & 0.005 & $\mathrm{mmol} \mathrm{cm} \mathrm{cm}^{-3} \mathrm{yr}^{-1}$ & fitted \\
\hline Attenuation coef. for decrease in sulfide removal rate & 0.07 & 0.6 & 0.05 & $\mathrm{~cm}^{-1}$ & fitted \\
\hline Non-local mixing coefficient & 1.5 & 0 & 80 & $\mathrm{yr}^{-1}$ & fitted \\
\hline Depth of irrigated layer & 15 & 0 & 2 & $\mathrm{~cm}$ & fitted \\
\hline Width of irrigated layer & 5 & 0 & 1.5 & $\mathrm{~cm}$ & fitted \\
\hline \multicolumn{6}{|l|}{ Porewater concentration upper/lower boundary } \\
\hline Bottom water/bottom sediment $\mathrm{SO}_{4}^{2-}$ & $28 / 0$ & $27 / 0$ & $27 / 0$ & $\mathrm{mmol} \mathrm{L}^{-1}$ & measured \\
\hline Bottom water/bottom sediment $\mathrm{CH}_{4}^{4}$ & $0 / 61$ & $0 / 61$ & $0 / 61$ & $\mathrm{mmol} \mathrm{L}^{-1}$ & calculated* \\
\hline Bottom water/bottom sediment $\mathrm{Cl}^{-}$ & $558 / 380$ & $548 / 320$ & $548 / 320$ & $\mathrm{mmol} \mathrm{L}^{-1}$ & measured \\
\hline Bottom water/bottom sediment $\mathrm{HCO}_{3}^{-}$ & $2.3 / 10$ & $4.0 / 15$ & $4.0 / 15$ & $\mathrm{mmol} \mathrm{L}^{-1}$ & measured \\
\hline Bottom water/bottom sediment sulfide & $0 / 0$ & $0.03 / 0.00$ & $0.03 / 0.00$ & $\mathrm{mmol} \mathrm{L}^{-1}$ & measured \\
\hline \multicolumn{6}{|l|}{ Model results } \\
\hline Methane flux at sediment bottom & 12.40 & 9.09 & 45.09 & $\mathrm{mmol} \mathrm{m}^{-2} \mathrm{~d}^{-1}$ & modeled \\
\hline Methane efflux at sediment-water interface & 0.98 & 0.00 & 3.39 & $\mathrm{mmol} \mathrm{m}^{-2} \mathrm{~d}^{-1}$ & modeled \\
\hline Percentage of consumed methane & 91.53 & 100.00 & 92.46 & $\%$ & modeled \\
\hline Anaerobic oxidation of methane & 11.35 & 9.09 & 41.69 & $\mathrm{mmol} \mathrm{m}^{-2} \mathrm{~d}^{-1}$ & modeled \\
\hline \multicolumn{6}{|l|}{ Measured turnover rates (radiotracer techniques) } \\
\hline Sulfate reduction (entire sediment depth) & $13.38 \pm 13.61$ & $218.90 \pm 159.80$ & $218.90 \pm 159.80$ & $\mathrm{mmol} \mathrm{m}^{-2} \mathrm{~d}^{-1}$ & measured \\
\hline AOM (entire sediment depth) & $12.87 \pm 5.98$ & $45.15 \pm 11.48$ & $45.15 \pm 11.48$ & $\operatorname{mmol~m}{ }^{-2} \mathrm{~d}^{-1}$ & measured \\
\hline
\end{tabular}

* Calculated after Tishchenko et al. (2005)

inflow methane concentration of $965 \pm 180 \mu \mathrm{mol} \mathrm{L}^{-1}$. Based on the pump rate, methane concentration, and surface area of the sediment, a methane flux of 0.28 and $2.81 \mathrm{mmol} \mathrm{m}^{-2} \mathrm{~d}^{-1}$ was calculated for the LFC and HFC, respectively. These methane concentrations were lower than those potentially encountered under in situ conditions because the cores were not pressurized, resulting in lower methane fluxes (after Tishchenko et al., 2005; Karaca et al., 2012). After 260 d the first experimental phase ended and the pump rates were increased from low to high flow velocities for the LFC, and vice versa for the HFC. This switch marked the beginning of the second and final experimental phase to study the response of AOM to rapid changes in the flow regime. After $316 \mathrm{~d}$, the experiment was terminated and the cores were sliced and subsampled for further analyses (see below).

Methane emission from the sediment was calculated by multiplying the outflow methane concentrations $\left(\mathrm{CH}_{4 \text { out }}\right)$ by the dilution factor (DF; 41 and 5 for LFC and HFC, respectively) and the fluid flow $\left(v ; 10.6\right.$ and $106.3 \mathrm{~cm} \mathrm{yr}^{-1}$ for LFC 
Table 3. Salt concentrations of the two different media used in the SLOT system. Seawater medium with sulfate was delivered from the top, whereas the seepage medium with methane and without sulfate was delivered from the bottom. In the last line, the gas in the respective medium's headspace is denoted.

\begin{tabular}{|c|c|c|}
\hline $\begin{array}{l}\text { Salts } \\
\left(\text { all in } \mathrm{mmol} \mathrm{L}^{-1} \text { ) }\right.\end{array}$ & $\begin{array}{r}\text { Seawater medium } \\
\text { (with } \mathrm{SO}_{4}^{2-} \text { ) }\end{array}$ & $\begin{array}{l}\text { Seepage medium } \\
\quad\left(\text { with } \mathrm{CH}_{4}\right)^{*}\end{array}$ \\
\hline $\mathrm{KBr}$ & 0.006 & 0.756 \\
\hline $\mathrm{KCl}$ & 8.05 & 8.05 \\
\hline $\mathrm{CaCl}_{2} \cdot 2 \mathrm{H}_{2} \mathrm{O}$ & 10.0 & 10.0 \\
\hline $\mathrm{MgCl}_{2} \cdot 6 \mathrm{H}_{2} \mathrm{O}$ & 27.9 & 55.5 \\
\hline $\mathrm{MgSO}_{2} \cdot 7 \mathrm{H}_{2} \mathrm{O}$ & 27.6 & 0.000 \\
\hline $\mathrm{NaCl}$ & 451 & 451 \\
\hline Medium headspace & $\mathrm{N}_{2}$ & $\mathrm{CH}_{4}$ \\
\hline
\end{tabular}

* $\mathrm{FeSO}_{4}$ (trace element) was replaced by $\mathrm{FeCl}$ (compare with Widdel and Bak, 2006)

Table 4. Overview of conditions during SLOT experiments: methane concentration of the "seepage" medium, methane flux, advective flow, and pump rate in the low- and high-flow core as well as experimental phases and run times under the low- and high-flow regime. The length of the sediment cores was 15 (LFC) and $14 \mathrm{~cm}$ (HFC).

\begin{tabular}{lrr}
\hline & $\begin{array}{r}\text { Low-flow } \\
\text { regime }\end{array}$ & $\begin{array}{r}\text { High-flow } \\
\text { regime }\end{array}$ \\
\hline Methane $\left(\mu \mathrm{mol} \mathrm{L}^{-1}\right)($ seepage medium) & \multicolumn{2}{c}{$965 \pm 180$} \\
Methane flux* $\left(\mathrm{mmol} \mathrm{m}^{-2} \mathrm{~d}^{-1}\right)$ & 0.28 & 2.81 \\
Advective flow $\left(\mathrm{cm} \mathrm{yr}^{-1}\right)$ & 10.6 & 106.3 \\
Pumping rate $\left(\mu \mathrm{L} \mathrm{min}^{-1}\right)$ (seepage medium) & 0.5 & 5 \\
Hydrological residence time (HRT) & 1080 & 108 \\
\hline Experimental phase & Total time & Phase time \\
\hline Initial & $-40-0$ & 40 \\
Phase 1 & $0-258$ & 258 \\
Phase 2 & $258-350$ & 92 \\
\hline${ }^{*}$ Calculated by the methane concentration of the seepage medium multiplied by the advective
\end{tabular}

flow.

and HFC, respectively) according to Eq. (1)

$$
\begin{aligned}
& \mathrm{CH}_{4 \text { out }}\left[\mathrm{mmol} \mathrm{m}^{-2} \mathrm{~d}^{-1}\right]=v\left[\mathrm{~cm} \mathrm{yr}^{-1}\right] \\
& \cdot \mathrm{CH}_{4 \text { out }}\left[\mathrm{mmol} \mathrm{cm}{ }^{-3}\right] \cdot \mathrm{DF} \cdot \frac{10000}{365.25} .
\end{aligned}
$$

Areal AOM rates were calculated from the difference between in- and outflow of methane before (258d) and after $(316 \mathrm{~d})$ fluid flow change. Therefore the methane efflux (Eq. 1) was subtracted from the methane flux (Table 4).

\subsection{Geochemical parameters during SLOT experimentation}

During the SLOT experiments, geochemical parameters were measured in $1 \mathrm{~cm}$ depth intervals throughout the sediment core. In addition, concentrations in the in- and outflowing fluids were monitored. Sulfide concentrations, $\mathrm{pH}$, and redox potential were measured with microsensors (sulfide needle sensor, $\mathrm{H}_{2} \mathrm{~S}-\mathrm{N}$, tip diameter $0.8 \mathrm{~mm}$, Unisense; $\mathrm{pH}, \mathrm{MI}$ $411 \mathrm{~B}$, gauge 20, Microelectrodes Inc.; redox potential needle sensors, MI-800, gauge 25, Microelectrodes Inc.). Porewater samples $(1.5-2 \mathrm{~mL})$ for the determination of sulfate, bromide, and total alkalinity were obtained from each depth in the sediment using pre-installed rhizones (CSS-F, length $5 \mathrm{~cm}$, diameter $2.5 \mathrm{~mm}$, pore size $0.2 \mu \mathrm{m}$, Rhizosphere $\left.{ }^{\circledR}\right)$. The in- and outflow of both cores were sampled with glass syringes for the determination of sulfate, bromide, total alkalinity and methane concentration. All sampling and measurement procedures for the experiment are described in detail by Steeb et al. (2014). Given a removal of $8.1 \%$ porewater during each rhizon sampling, which causes mixing with adjacent layers, and an analytical precision of $<1 \%$ (ion chromatography) and $0.1 \%$ (total alkalinity titration), we estimated a total analytical uncertainty of ca. $9 \%$ for sulfate and bromide and $8.2 \%$ for total alkalinity.

\subsection{Experiment termination and final sampling}

At the end of the experiment, $1.5 \mathrm{~mL}$ porewater from each depth was sampled for determinations of sulfide $(0.5 \mathrm{~mL})$, sulfate and bromide $(0.5 \mathrm{~mL})$ as well as total alkalinity $(0.5 \mathrm{~mL})$ and analyzed using the same methods as the ex situ porewater (see Sect. 2.1).

After the final porewater sampling, sediment subsamples were taken from each SLOT core. Two subcores (polycarbonate, length $260 \mathrm{~mm}$, inner diameter $26 \mathrm{~mm}$ ) were collected from each SLOT core for radiotracer determinations of $\mathrm{AOM}$ and sulfate reduction and treated according to the protocols mentioned above. For the determination of methane concentrations, each SLOT core was sampled at $1 \mathrm{~cm}$ intervals $\left(2 \mathrm{~cm}^{3}\right.$ volume subsamples $)$ using cut-off syringes ( $3 \mathrm{~mL}, \mathrm{PE}$ ). The sediment samples were transferred into glass vials $(13 \mathrm{~mL})$ with $5 \mathrm{~mL}$ of $2.5 \% w / v \mathrm{NaOH}$. Vials were closed with butyl rubber stoppers and shaken directly after sampling. Methane was analyzed by gas chromatography (Hewlett Packard Series II) with a packed column (Haye SepT, 6 ft, $3.1 \mathrm{~mm}$ inner diameter, 100/120 mesh, Resteck; carrier gas: He $20 \mathrm{~mL} \mathrm{~min}^{-1}$; combustion gas: synthetic air $240 \mathrm{~mL} \mathrm{~min}^{-1}, \mathrm{H}_{2} 20 \mathrm{~mL} \mathrm{~min}^{-1}$ ).

The remaining sediment of each SLOT core was sampled in $2 \mathrm{~cm}$ depth intervals. For porosity measurements, approximately $2 \mathrm{~cm}^{3}$ samples were obtained using cut-off syringes ( $3 \mathrm{~mL}, \mathrm{PE})$, transferred to pre-weighed vials, and weighed before and after the sample was freeze-dried. Porosity was then calculated by the difference in weight (Dalsgaard et al., 2000). Subsamples of the dried sediment were used to determine total carbon (TC), total nitrogen (TN), total sulfur (TS) and total organic carbon (TOC) of the solid phase. TC, TN, TS, and TOC were analyzed using a Carlo Erba NA 1500 elemental analyzer. For TOC determination, inorganic carbon was removed by adding hydrochloric acid. Total inorganic 
carbon (TIC) was calculated from the difference between TC and TOC. All solid-phase analyses were carried out in duplicates.

Further details on the SLOT sampling procedure and analytical procedures are described in Steeb et al. (2014).

\section{Results}

\subsection{Ex situ profiles and numerical models}

Both MUC cores (SO206-29 MUC and SO206-31 MUC) were sampled at $\sim 400 \mathrm{~m}$ water depth from sediments covered with sulfur bacteria mats, which are indicative of high methane fluxes (Torres et al., 2002; Treude et al., 2003).

At station SO-206-29 (MUC), sulfate decreased from $28 \mathrm{mmol} \mathrm{L}^{-1}$ at the sediment surface to zero at the bottom of the core $(26 \mathrm{cmbsf})$ (Fig. 1a). Conversely, methane concentrations were low $\left(0.0-0.1 \mathrm{mmol} \mathrm{L}^{-1}\right)$ in the upper $15 \mathrm{cmbsf}$ and increased below this zone to a maximum of $2.4 \mathrm{mmol} \mathrm{L}^{-1}$ at the bottom (Fig. 1a). Accordingly, the SMTZ was located at $17.5 \mathrm{cmbsf}$. Two maxima in sulfate reduction rates were identified in one of the replicate cores at the top (up to $1821 \mathrm{nmol} \mathrm{cm}^{-3} \mathrm{~d}^{-1}$ ) and between 12.5 and $22.5 \mathrm{cmbsf}$ (up to $879 \mathrm{nmol} \mathrm{cm}^{-3} \mathrm{~d}^{-1}$ ) (Fig. 1b). AOM coincided with the second sulfate reduction maximum and reached rates of up to $569 \mathrm{nmol} \mathrm{cm}^{-3} \mathrm{~d}^{-1}$ (Fig. 1c). Sulfide and total alkalinity (TA) increased from the top $\left(0.0 \mathrm{mmol} \mathrm{L}^{-1}\right.$ and $2.5 \mathrm{meq} \mathrm{L}^{-1}$, respectively) to a maximum within the SMTZ $\left(7.9 \mathrm{mmol} \mathrm{L}^{-1}\right.$ and $23.4 \mathrm{meq} \mathrm{L}^{-1}$, respectively, at $17.5 \mathrm{~cm}$ sediment depth) (Fig. 1d). Areal turnover rates of methane and sulfate integrated over the entire sediment depth of $26 \mathrm{~cm}$ were similar for AOM (on average $12.87 \pm 5.98 \mathrm{mmol} \mathrm{m}^{-2} \mathrm{~d}^{-1}$ ) and sulfate reduction (on average $13.38 \pm \mathrm{SD} 13.61 \mathrm{mmol} \mathrm{m}^{-2} \mathrm{~d}^{-1}$ ), with a ratio of 0.96 (AOM : sulfate reduction).

The steady-state model resulted in a fluid flow of $7 \mathrm{~cm} \mathrm{yr}^{-1}$ and an areal AOM rate of $11.35 \mathrm{mmol} \mathrm{m}^{-2} \mathrm{~d}^{-1}$ (Table 2). In total, around $92 \%$ of the delivered methane was oxidized by AOM and $\sim 8 \%$ was released to the seawater. Fitted porewater profiles and AOM rates are shown in Fig. 1.

In the second core, SO206-31 (MUC), sulfate decreased to $0 \mathrm{mmol} \mathrm{L}^{-1}$ within the first $15 \mathrm{~cm}$ sediment depth, and considerable methane concentrations $\left(>3.4 \mathrm{mmol} \mathrm{L}^{-1}\right)$ were observed at $5 \mathrm{cmbsf}$ (Fig. 2a). The observed maximum methane concentration was $10.2 \mathrm{mmol} \mathrm{L}^{-1}(20.5 \mathrm{cmbsf})$. Accordingly, the SMTZ was located at approximately $5-15 \mathrm{cmbsf}$ Sulfate reduction and AOM occurred between 0 and $12.5 \mathrm{cmbsf}$ with a sulfate reduction maximum $\left(12052 \mathrm{nmol} \mathrm{cm}^{-3} \mathrm{~d}^{-1}\right)$ at the top of the SMTZ $(\sim 2.5 \mathrm{cmbsf})$ and an AOM maximum $\left(1400 \mathrm{nmol} \mathrm{cm}^{-3} \mathrm{~d}^{-1}\right)$ in the upper part of the SMTZ $(5.5 \mathrm{~cm} \mathrm{cmbsf})$ (Fig. 2b, v). Highest sulfide and TA concentrations were measured within the SMTZ between 10 and $15 \mathrm{cmbsf}\left(8.6 \mathrm{mmol} \mathrm{L}^{-1}\right.$ and $24.1 \mathrm{meq} \mathrm{L}^{-1}$, respectively) (Fig. 2d). Areal sulfate reduction rates integrated over the entire sediment depth of $25 \mathrm{~cm}\left(218.90 \pm 159.80 \mathrm{mmol} \mathrm{m}^{-2} \mathrm{~d}^{-1}\right)$ were around 5 times (AOM : $\mathrm{SR}=0.21)$ higher compared to the areal rates of AOM $\left(45.15 \pm 11.48 \mathrm{mmol} \mathrm{m}^{-2} \mathrm{~d}^{-1}\right)$ integrated over the same depth.

Replicate cores from SO206-31 taken for porewater and rate analyses showed a different depth of the SMTZ and the AOM peak, respectively. Based on this lateral heterogeneity, two different fits of AOM were applied in the numerical model: one for the porewater core (pw-fit) and one for the rate core (hf-fit), which required a higher fluid advection to align the modeled and measured AOM (for details see Table 2). The pw-fit with $7 \mathrm{~cm} \mathrm{yr}^{-1}$ fluid flow showed an efficient benthic filter which oxidized all delivered methane $\left(9.09 \mathrm{mmol} \mathrm{m}^{-2} \mathrm{~d}^{-1}\right)$. The hf-fit $\left(29 \mathrm{~cm} \mathrm{yr}^{-1}\right)$ had an AOM rate of $41.69 \mathrm{mmol} \mathrm{m}^{-2} \mathrm{~d}^{-1}$ and oxidized around $93 \%$ of the delivered methane $\left(45.09 \mathrm{mmol} \mathrm{m}^{-2} \mathrm{~d}^{-1}\right)$. Model results are shown in Fig. 2 and summarized in Table 2.

\subsection{SLOT incubation experiments}

For the SLOT incubations, two replicate cores from SO20631 (MUC) were used.

\subsubsection{Evolution of biogeochemical parameters during the main phase of the experiment $(0-260 \mathrm{~d})$}

\section{The low fluid flow regime core}

In the LFC incubations, bromide concentration, which was used as a tracer to track the seepage medium, was always very low and near the detection limit $\left(20 \mu \mathrm{mol} \mathrm{L}^{-1}\right)$. Values increased only weakly in the lowest $5 \mathrm{~cm}$ of the core, reaching a maximum of $45 \mu \mathrm{mol} \mathrm{L}^{-1}$ after $49 \mathrm{~d}$ (Fig. 3d). After $105 \mathrm{~d}$, a small concentration of bromide $\left(<3 \mathrm{mmol} \mathrm{L}^{-1}\right)$ appeared in the supernatant, which later $(171 \mathrm{~d})$ disappeared again. Sulfate, which was delivered from the top by diffusion, decreased only slightly at the bottom of the core $\left(27.2 \mathrm{mmol} \mathrm{L}^{-1}\right)$ due to a slow advection of methaneenriched seepage medium. This was in accordance with the small increase in bromide (up to $\sim 45 \mu \mathrm{mol} \mathrm{L}^{-1}$ ). After $105 \mathrm{~d}$, sulfate levels stabilized around $26 \mathrm{mmol} \mathrm{L}^{-1}$ at the bottom of the core and did not further decrease during the low-flow phase.

In the first $105 \mathrm{~d}$, sulfide concentrations of the LFC varied between 23 and $300 \mu \mathrm{mol} \mathrm{L}^{-1}$ over depth with a maximum between 9 and $11 \mathrm{~cm}$ (Fig. 3b, e, h). After $171 \mathrm{~d}$, a sulfide peak $\left(920 \mu \mathrm{mol} \mathrm{L}{ }^{-1}\right.$, Fig. $\left.3 \mathrm{k}\right)$ occurred at $0.26 \mathrm{~cm}$ sediment depth, while no sulfide was detected in the overlying water. Below the peak, sulfide varied between 300 and $500 \mu \mathrm{mol} \mathrm{L}^{-1}$. Thirty days later ( $201 \mathrm{~d}$ of runtime), maximum sulfide concentrations of up to $230 \mu \mathrm{mol} \mathrm{L}^{-1}$ were observed between 1.5 and $10.7 \mathrm{~cm}$ sediment depth (Fig. 3n). After $258 \mathrm{~d}$, directly before changing from low to high fluid flow, maximum sulfide concentrations were $115 \mu \mathrm{mol} \mathrm{L}^{-1}$ 


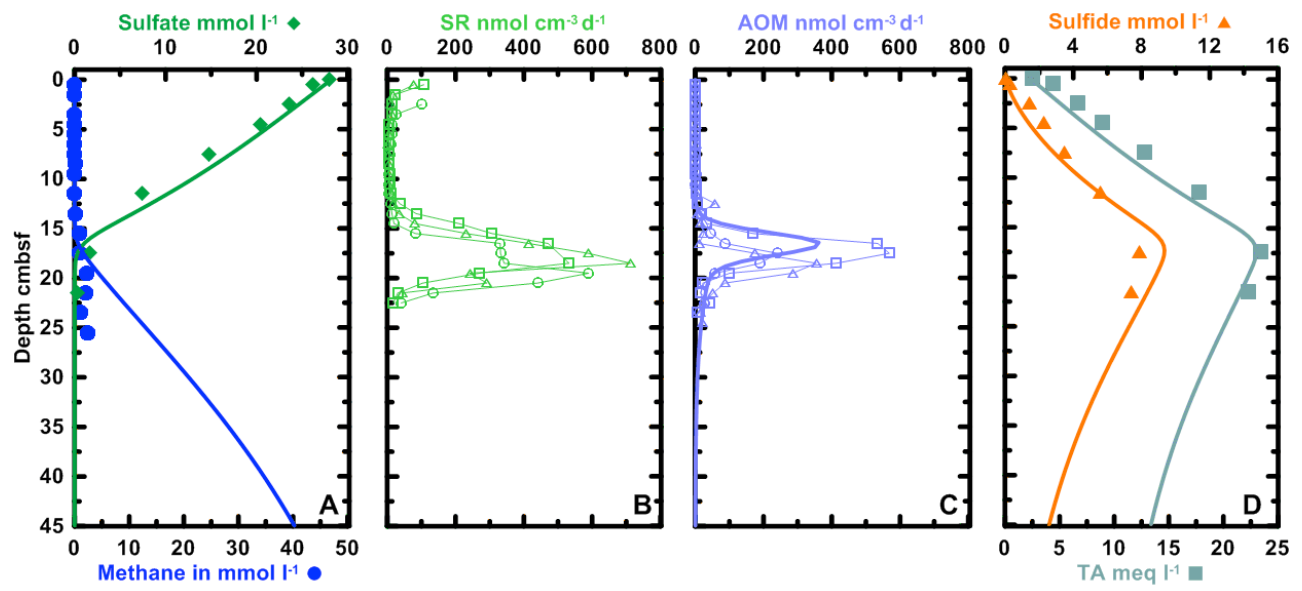

Figure 1. Depth profiles of measured and modeled porewater parameters and microbial turnover rates for SO206-29 (MUC), sampled from $402 \mathrm{~m}$ water depth. (a) Measured (diamonds) and modeled (thick green line) sulfate concentrations (per Vol porewater), as well as measured (circles) and modeled (thick blue line) methane concentrations (per Vol sediment). (b) Three replicates (thin lines and symbols) of measured sulfate reduction rates (per Vol sediment). (c) Three replicates of measured (thin lines and symbols) and modeled (thick line) AOM rates (per Vol sediment). (d) Measured (triangles) and modeled sulfide concentration (thick orange line), as well as measured (squares) and modeled (thick grey line) total alkalinity (per Vol porewater).
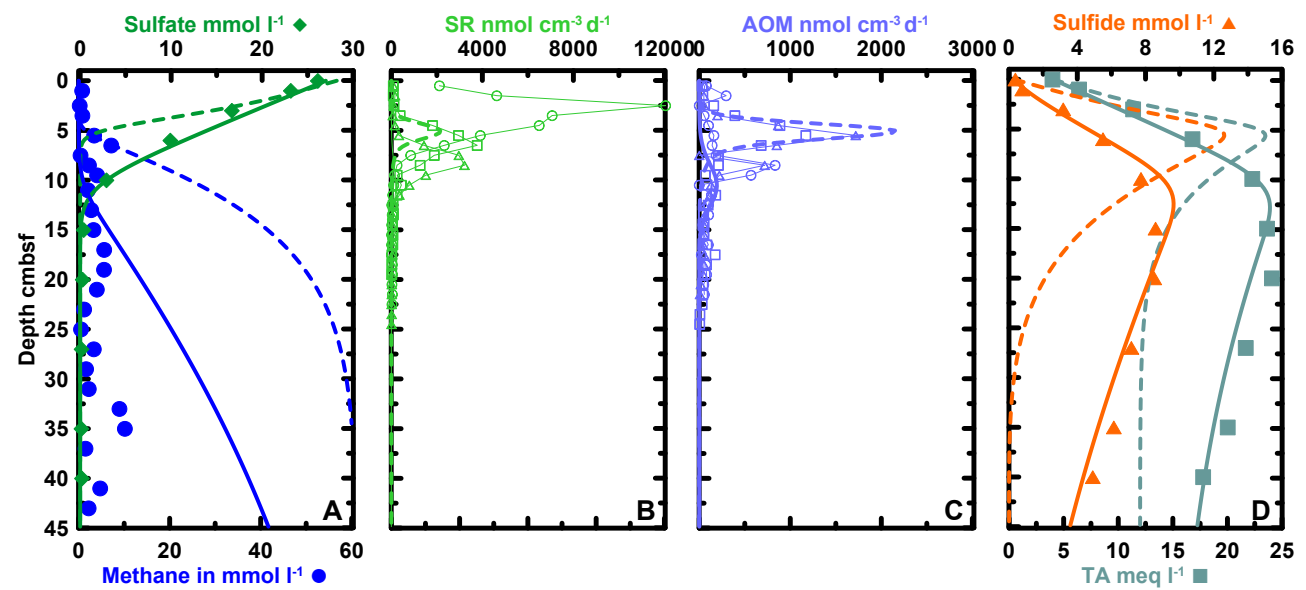

Figure 2. Depth profiles of measured and modeled porewater parameters and microbial turnover rates for SO206-31 (MUC) sampled from $401 \mathrm{~m}$ water depth. Thick solid lines: pw-fit model; thick dashed lines: hf-fit model (for details see Results). (a) Measured (diamonds) and modeled (thick green lines) sulfate concentrations (per L porewater), as well as measured (circles) and modeled (thick blue lines) methane concentrations (per L sediment). (b) Three replicates (thin lines and symbols) of measured sulfate reduction rates (per $\mathrm{cm}^{-3}$ sediment). (c) Three replicates of measured (thin lines and symbols) and modeled (thick lines) AOM rates (per $\mathrm{cm}^{-3}$ sediment). (d) Measured (triangles) and modeled (thick orange lines) sulfide concentration, as well as measured (squares) and modeled (thick grey lines) total alkalinity (per L porewater).

at $4.5-5.5 \mathrm{cmbsf}$ (Fig. $3 \mathrm{q}$ ) and decreased to a minimum of $36 \mu \mathrm{mol} \mathrm{L}^{-1}$ near the sediment-water interface.

TA was predominantly lower inside the cores than in the media ( $30 \mathrm{meq} \mathrm{L}^{-1}$ ). During the LFC incubation, TA continuously decreased over the time from $\sim 30$ to $\sim 24 \mathrm{meq}^{-1}$ below $\sim 9 \mathrm{~cm}$ (Fig. 3b, e, h, k). After $171 \mathrm{~d}$, TA varied between 28.7 and $21.7 \mathrm{meq} \mathrm{L}^{-1}$. Directly before the change of fluid flow (258 d), TA increased from the top (23.3 meq $\mathrm{L}^{-1}$ ) to the bottom (26.7 meq $\mathrm{L}^{-1}$; Fig. 3q).
Initial redox potential of the $\mathrm{LFC}$ was $-50 \mathrm{mV}$ at the top and around $-150 \mathrm{mV}$ below $2 \mathrm{~cm}$ sediment depth (Fig. 3c). After $49 \mathrm{~d}$, the redox potential was more negative $(-130 \mathrm{mV}$ at top and between -160 and $-270 \mathrm{mV}$ below, Fig. 3f); after $105 \mathrm{~d}$, the redox potential increased to $-80 \mathrm{mV}$ at the top (Fig. 3i). Between 171 and $202 \mathrm{~d}$ of runtime, the overlying water of the core showed a pink color caused by the oxygen indicator resazurin. At the same time, the redox potential was positive (between 150 and $100 \mathrm{mV}$ ) at the sediment-water 

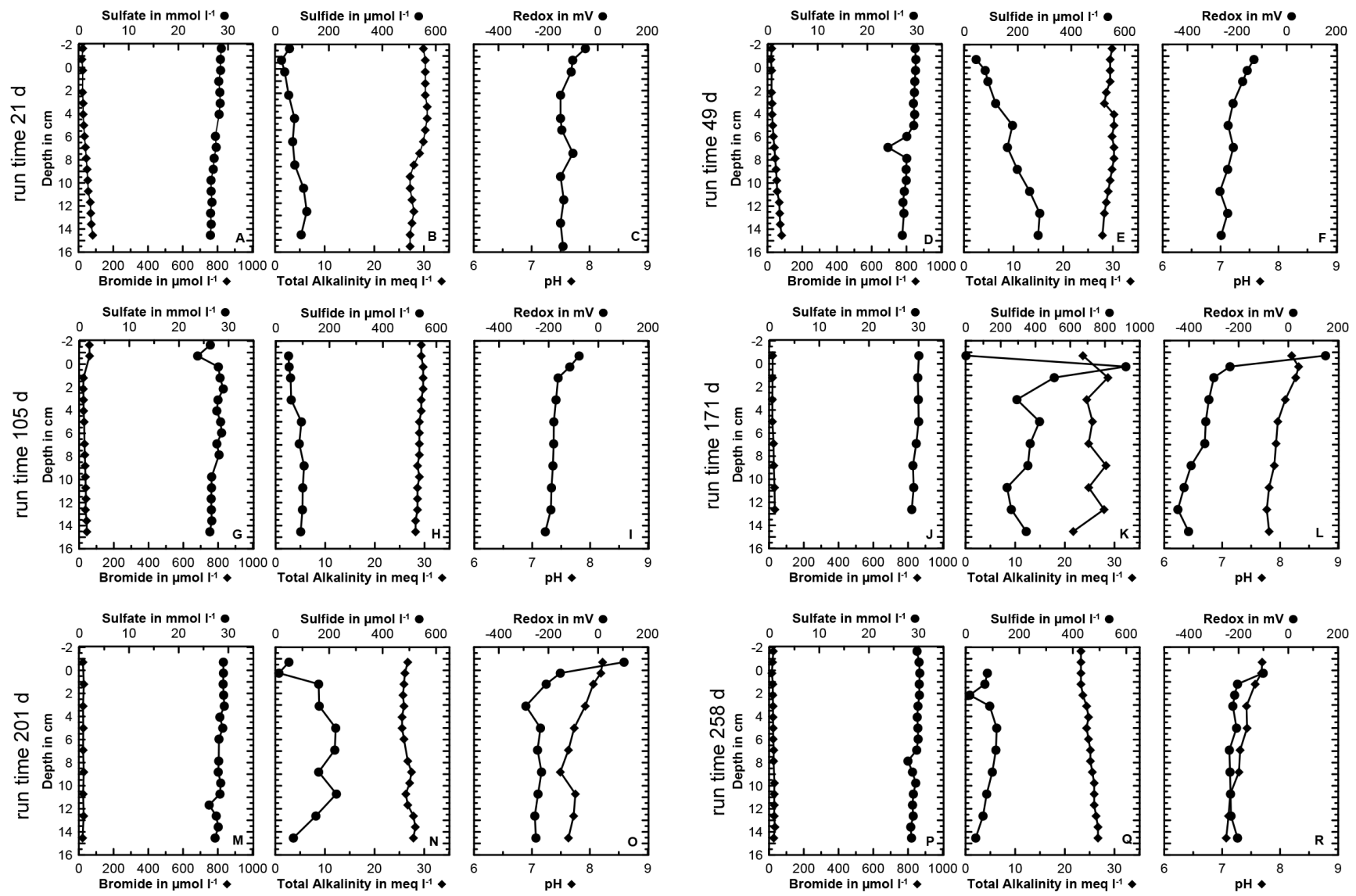

fluid flow changed from low $\left(10.63 \mathrm{~cm} \mathrm{yr}^{-1}\right)$ to high $\left(106.3 \mathrm{~cm} \mathrm{yr}^{-1}\right)$
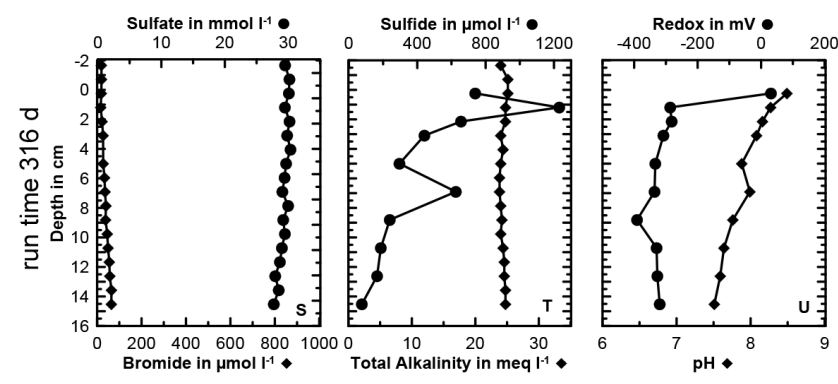

Figure 3. Sulfate and bromide concentrations (left panels), sulfide and total alkalinity concentrations (middle panels), and redox potential and $\mathrm{pH}$ (right panels) measured in the sediment of the low-flow regime core (LFC) from Quepos Slide after different days of runtime indicated on the left. All concentrations are presented as per liter of porewater. Please note the different scales for sulfide concentrations.

interface (Fig. 31, o), probably as a result of oxygen intrusion. Nevertheless, free oxygen should result in a redox potential $>350 \mathrm{mV}$ (Schulz, 2000). We therefore assume that oxygen was only temporally available and rapidly consumed. Deeper inside the sediment, redox potential reached values between -200 and $-400 \mathrm{mV}$ (Fig. 31, o).

Directly before changing the fluid flow (258 d), the redox potential of the LFC was $-100 \mathrm{mV}$ in the overlying water and around $-200 \mathrm{mV}$ inside the sediment (Fig. 3r).

After $171 \mathrm{~d}$ of runtime, $\mathrm{pH}$ was highest at the sedimentwater interface (8.2, Fig. 31) and around 7.6 deeper in the sediment. Final $\mathrm{pH}$ before fluid flow swapping (258 d) decreased from 7.6 at the top to 7.1 at the bottom of the core (Fig. 3r).

Methane concentrations in the outflow of the LFC started at $1.5 \mu \mathrm{mol} \mathrm{L}-1(29 \mathrm{~d})$ and increased to $2.5 \mu \mathrm{mol} \mathrm{L}-1$ after $105 \mathrm{~d}$ before decreasing again to $0.9 \mu \mathrm{mol} \mathrm{L}^{-1}$ after $258 \mathrm{~d}$ (Fig. 5). Calculated methane efflux followed the methane concentration trend. The LFC methane efflux was between 0.011 and $0.030 \mathrm{mmol} \mathrm{m}^{-2} \mathrm{~d}^{-1}$. AOM rates from the difference of in- and outflow were $0.269 \mathrm{mmol} \mathrm{m}^{-2} \mathrm{~d}^{-1}$, directly before changing the fluid flow regime. However, this rate 
must overestimate the actual AOM activity, because the core did not reach steady state before the fluid flow change, as the bromide front did not reach the sediment-water interface (see discussion).

\section{The high fluid flow regime core}

In the HFC, bromide quickly appeared after $21 \mathrm{~d}$ $\left(400 \mu \mathrm{mol} \mathrm{L}^{-1}\right)$ at the bottom of the core (Fig. 4a). Bromide concentration continuously increased from the bottom towards the top of the core until a chemocline developed between 4 and $10 \mathrm{~cm}$ sediment depth after $105 \mathrm{~d}$ (Fig. 4g). This chemocline persisted during the remaining experiment and moved slowly upwards reaching a zone between 1 and $6 \mathrm{~cm}$ depth after $258 \mathrm{~d}$ (Fig. 4a, d). Sulfate concentrations during the HFC period were opposite to the bromide distribution and coincided with the chemocline. Sulfate continuously decreased towards the bottom of the core reaching the minimum concentration $\left(0.2 \mathrm{mmol} \mathrm{L}^{-1}\right)$ after $201 \mathrm{~d}$ (Fig. $4 \mathrm{~m}$ ). Simultaneously, sulfate was more and more displaced from the bottom to the top of the core, decreasing from 28.5 to $12 \mathrm{mmol} \mathrm{L}^{-1}$ at the sediment-water interface.

Sulfide concentrations were considerably lower compared to the LFC. At the beginning ( $21 \mathrm{~d}$ ), sulfide increased from the top $\left(27 \mu \mathrm{mol} \mathrm{L}^{-1}\right)$ to $6 \mathrm{~cm}$ sediment depth $\left(70 \mu \mathrm{mol} \mathrm{L}{ }^{-1}\right)$ within the developing SBTZ (Fig. 4b), which was used as proxy for the SMTZ, and was constant at this level below $6 \mathrm{~cm}$ sediment depth. In the following months, sulfide decreased below $20 \mu \mathrm{mol} \mathrm{L}^{-1}$ (105 d) and increased rapidly after $171 \mathrm{~d}$ of runtime at the top of the core to more than $500 \mu \mathrm{mol} \mathrm{L}^{-1}$ (Fig. 4k). In the following months, sulfide concentrations decreased again at first to maximum values of $300 \mu \mathrm{mol} \mathrm{L}^{-1}(4 \mathrm{~cm}$ sediment depth, $202 \mathrm{~d}$ of runtime) and to less than $60 \mu \mathrm{mol} \mathrm{L}^{-1}$ after $258 \mathrm{~d}$ (Fig. 4q).

TA in the HFC showed similar trends to the LFC. Near the start (21 d), TA decreased from 29 to $30 \mathrm{meq} \mathrm{L}^{-1}$ at the top of the core to $26-27 \mathrm{meq} \mathrm{L}^{-1}$ at the bottom (Fig. $4 \mathrm{~b}, \mathrm{e}, \mathrm{h}$ ). After $171 \mathrm{~d}$, this distribution reversed with TA increasing from the top of the core to the bottom, from $21-26$ to $24-27$ meq $\mathrm{L}^{-1}$ (Fig. 4k).

The redox potential of the HFC was, similar to the LFC, highest at the sediment-water interface and in the overlying water and lowest at larger depths of the core. Initially (21 d), redox potential was $-85 \mathrm{mV}$ at the sediment-water interface and between -100 and $-150 \mathrm{mV}$ in the sediment (Fig. 4c). Over time, the redox potential in the sediment became more negative, reaching a value as low as $-385 \mathrm{mV}$ after $105 \mathrm{~d}$ (Fig. 4i, 1). Between 105 and $202 \mathrm{~d}$ of runtime, the overlying water turned pink and showed a redox potential ranging from 100 to $200 \mathrm{mV}$ (Fig. 4q), indicating oxygen contamination in the core. Directly before the change in fluid flow, the redox potential returned to negative values, with $-120 \mathrm{mV}$ in the overlying water and around $-200 \mathrm{mV}$ in remaining core (Fig. 4r).
Similar to the LFC, the pH was highest at the sedimentwater interface and lower inside the sediment (8.1-7.8 after $171 \mathrm{~d}$ and $8.0-7.4$ after $202 \mathrm{~d}$; Fig. 41, o). Directly before the fluid flow change $(258 \mathrm{~d}), \mathrm{pH}$ decreased to 7.6 at the sediment-water interface and 7.1-7.3 inside the sediment (Fig. 4r).

Methane concentration in the HFC outflow was initially (21 d) $7.5 \mu \mathrm{mol} \mathrm{L}^{-1}$ and then decreased to $1.7 \mu \mathrm{mol} \mathrm{L}^{-1}$ during the following $200 \mathrm{~d}$. After $258 \mathrm{~d}$ of runtime, methane concentration in the outflow increased again to $2.8 \mu \mathrm{mol} \mathrm{L}^{-1}$. Efflux of the HFC ranged from 0.025 to $0.109 \mathrm{mmol} \mathrm{m}^{-2} \mathrm{~d}^{-1}$. Corresponding calculated AOM rates were $2.77 \mathrm{mmol} \mathrm{m}^{-2} \mathrm{~d}^{-1}$ directly before changing the flow rate $(258 \mathrm{~d})$.

\subsubsection{Biogeochemical responses after changing the fluid flow regime (260-350 d of runtime)}

After $260 \mathrm{~d}$, the fluid flow in the cores was swapped from low to high and vice versa.

\section{New high-flow regime core}

In the new high-flow regime core (NHFC, formerly LFC) sulfate and bromide concentrations did not change considerably over the entire runtime ( $350 \mathrm{~d}$ ). TA remained constant at $25 \mathrm{meq} \mathrm{L}^{-1}$ (Fig. 3t). Sulfide concentrations were highest at $0.3 \mathrm{~cm}$ sediment depth $\left(1230 \mu \mathrm{mol} \mathrm{L}^{-1}\right)$ and first decreased steeply followed by a more steady increase (below $3 \mathrm{~cm}$ ) with the exception of a second maximum $\left(625 \mu \mathrm{mol} \mathrm{L}{ }^{-1}\right)$ at $5 \mathrm{~cm}$. At the bottom of the core, a sulfide concentration of $\max 75 \mu \mathrm{mol} \mathrm{L}{ }^{-1}$ was reached. Redox potential was positive $(31 \mathrm{mV})$ in the overlying water and between -280 and $-330 \mathrm{mV}$ within the sediment (Fig. $3 \mathrm{u}$ ). The $\mathrm{pH}$ decreased from 8.5 to 7.5 between the sediment-water interface and the bottom of the core.

Methane concentration of the outflow increased considerably from 0.9 to $11.6 \mu \mathrm{mol} \mathrm{L}^{-1}$ after $316 \mathrm{~d}$ run time (Fig. 5). Calculated methane effluxes were $0.165 \mathrm{mmol} \mathrm{m}^{-2} \mathrm{~d}^{-1}$ and corresponding AOM rates were $2.64 \mathrm{mmol} \mathrm{m}^{-2} \mathrm{~d}^{-1}$. Similar to the LFC, the AOM rate is most likely overestimated, as the core did not reach steady state (see discussion).

\section{New low-flow regime core}

In the new low-flow regime core (NLFC, formerly HFC), sulfate penetrated deeper and bromide ascended less into the sediment as compared to the profile prior to fluid flow change (Fig. 4s). Sulfide concentrations remained low, between 50 and $80 \mu \mathrm{mol} \mathrm{L}^{-1}$, and TA varied between 23 and $25 \mathrm{meq} \mathrm{L}^{-1}$ (Fig. 4t). Redox potential was positive $(150 \mathrm{mV})$ at the sediment-water interface and the upper sediment (Fig. 4u). Below $2 \mathrm{~cm}$ sediment depth, redox decreased to values between -200 and $-400 \mathrm{mV}$. The $\mathrm{pH}$ profile decreased from 8.05 in the overlying water and at the sediment-water interface down to 7.55 below $6 \mathrm{~cm}$ sediment depth. 

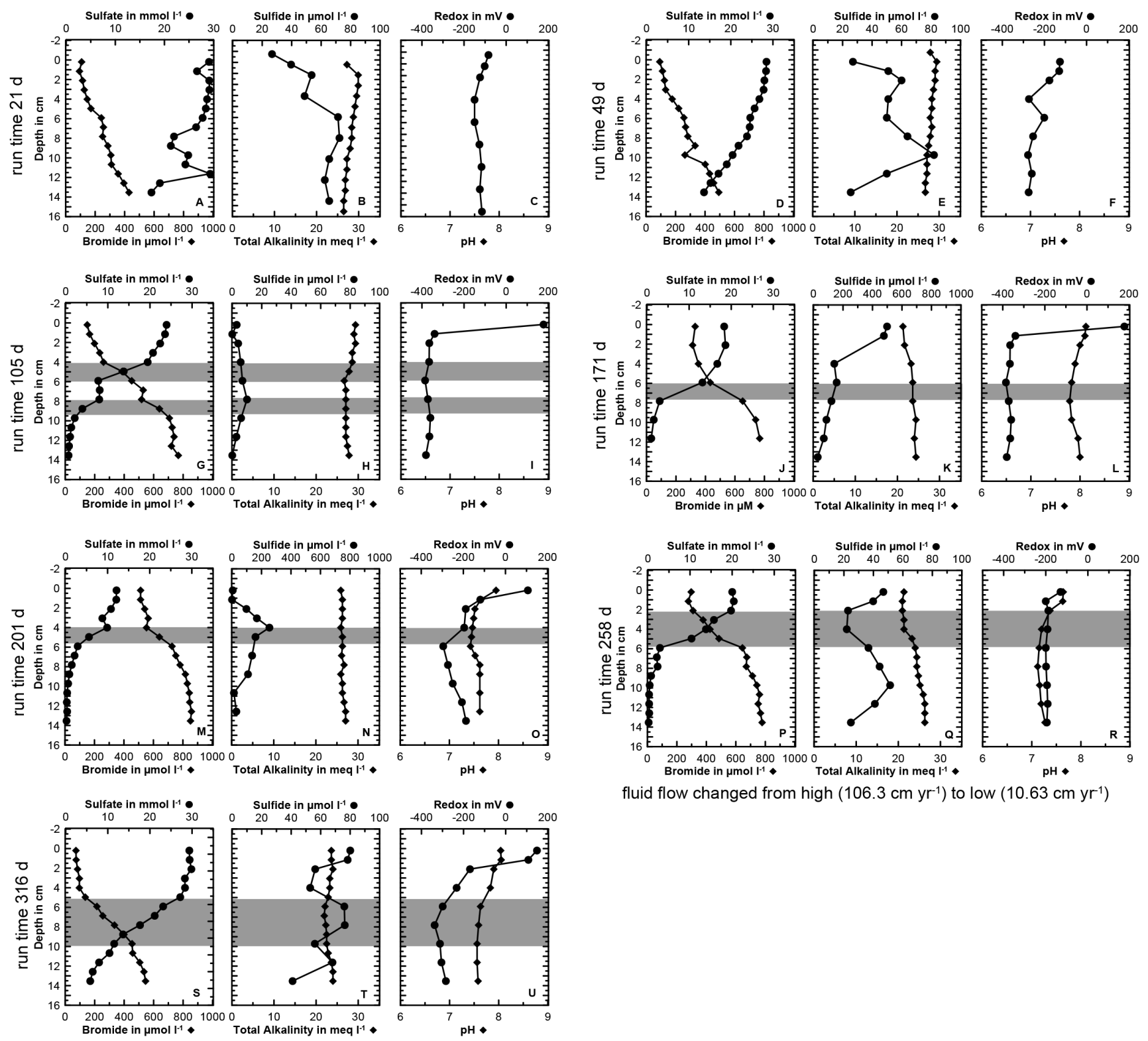

fluid flow changed from high $\left(106.3 \mathrm{~cm} \mathrm{yr}^{-1}\right)$ to low $\left(10.63 \mathrm{~cm} \mathrm{yr}^{-1}\right)$

Figure 4. Sulfate and bromide concentrations (left panels), sulfide and total alkalinity concentrations (middle panels), and redox potential and $\mathrm{pH}$ (right panels) measured in the sediment of the high-flow regime core (HFC) from Quepos Slide after days of runtime indicated on the left. The SBTZ as proxy for the SMTZ is highlighted by the grey bar. All concentrations are presented as per liter of porewater. Please note the different scales for sulfide concentrations.

Methane concentrations in the outflow declined from 2.8 to $0.7 \mu \mathrm{mol} \mathrm{L}^{-1}$ (Fig. 5). Calculated methane effluxes were $0.009 \mathrm{mmol} \mathrm{m}^{-2} \mathrm{~d}^{-1}$ with a corresponding AOM rate of $0.271 \mathrm{mmol} \mathrm{m}^{-2} \mathrm{~d}^{-1}$.

\subsubsection{Biogeochemical parameters after experiment termination}

After $350 \mathrm{~d}$ of runtime, the experiment was terminated, porewater was sampled, and the sediment subsampled for further analyses. In both cores, methane concentrations deter- mined after experiment termination (around $2.5 \mu \mathrm{mol} \mathrm{L}{ }^{-1}$ ) were only a minor fraction of the original inflow concentration $\left(965 \mu \mathrm{mol} \mathrm{L}{ }^{-1}\right)$, which was probably mostly attributed to methane losses during porewater extraction using rhizones directly before sediment sampling (Steeb et al., 2014). In the NHFC (formerly LFC) methane concentrations varied between 2 and $4 \mu \mathrm{mol} \mathrm{L}{ }^{-1}$, with a slight increase towards the bottom of the core (Fig. 6a). Sulfate concentrations decreased slightly from $29.5 \mathrm{mmol} \mathrm{L}^{-1}$ at the top to $26.2 \mathrm{mmol} \mathrm{L}^{-1}$ at the bottom of the core (Fig. 6b). Sulfide increased from $50 \mathrm{mmol} \mathrm{L}^{-1}$ at the sed- 

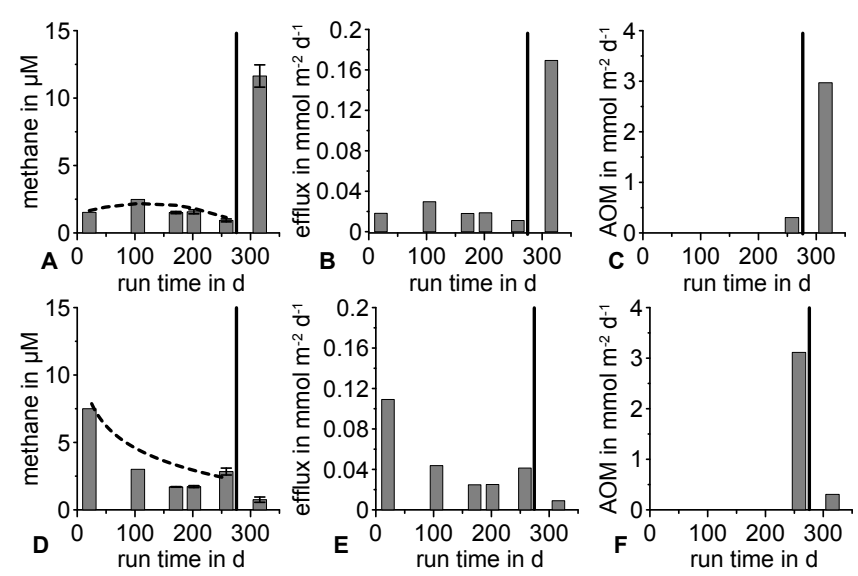

Figure 5. Methane concentration $\left(\mu \mathrm{mol} \mathrm{L}{ }^{-1}\right)$ in the outflow (a, d), methane efflux $\left(\mathrm{mmol} \mathrm{m}{ }^{-2} \mathrm{~d}^{-1} ; \mathbf{b}, \mathbf{e}\right)$, and calculated AOM rate $\left(\mathrm{mmol} \mathrm{m}^{-2} \mathrm{~d}^{-1} ; \mathbf{c}, \mathbf{f}\right)$ of the SLOT system before and after changing the fluid flow regime: $(\mathbf{a}, \mathbf{b}, \mathbf{c})$ low-flow regime core (LFC) and (d, e, f) high-flow regime core (HFC) from Quepos Slide. Vertical lines mark the moment of fluid flow change (low flow $\rightarrow$ high flow and vice versa at $258 \mathrm{~d}$ of runtime). Error bars $((\mathbf{a}, \mathbf{d}))$ show standard deviations of three repeated gas chromatographic measurements; the first two data points represent single measurements. Dotted lines represent the trend line (lowflow regime: $5 \times 10^{-6} \times t_{\text {runtime }}^{2}+0.02 t_{\text {runtime }}+0.285, r^{2}=0.825$; high-flow regime: $\left.0.8576 \times \ln \left(t_{\text {runtime }}\right)-0.8662, r^{2}=0.987\right)$ of methane concentration development until flow change.

iment surface $(0.3 \mathrm{~cm})$ to a maximum of $125 \mu \mathrm{molL}^{-1}$ at $6 \mathrm{~cm}$ and decreased to $80 \mu \mathrm{mol} \mathrm{L}-1$ at the bottom of the core (Fig. 6c). AOM rates of the NHFC determined by radiotracer techniques showed highest values between 4 and $10 \mathrm{~cm}$ sediment depth $\left(0.50-0.91 \mathrm{nmol} \mathrm{cm}^{-3} \mathrm{~d}^{-1}\right)$ and, in addition, increased from top $\left(0.10 \mathrm{nmol} \mathrm{cm}{ }^{-3} \mathrm{~d}^{-1}\right)$ to bottom $\left(0.33 \mathrm{nmol} \mathrm{cm}^{-3} \mathrm{~d}^{-1}\right)$. Areal turnover rates of methane and sulfate integrated over the entire sediment core $(0-15 \mathrm{~cm})$ were 0.043 and $2.31 \mathrm{mmol} \mathrm{m}^{-2} \mathrm{~d}^{-1}$ for AOM and sulfate reduction, respectively.

In the NLFC (formerly HFC), methane concentrations remained consistently low at around $2-4 \mu \mathrm{mol} \mathrm{L}^{-1}$ (Fig. 7a). Sulfate was between 27 and $28.5 \mathrm{mmol} \mathrm{L}^{-1}$ within the upper first $6 \mathrm{~cm}$ and then decreased to $10 \mathrm{mmol} \mathrm{L}^{-1}$ below this depth (Fig. 7b). Consistent with the steepest decrease in sulfate, sulfide increased to a maximum of $42 \mu \mathrm{mol} \mathrm{L}^{-1}$. Highest AOM rates determined with radiotracer techniques were detected between 5 and $11 \mathrm{~cm}(0.4-$ $1 \mathrm{nmol} \mathrm{cm}{ }^{-3} \mathrm{~d}^{-1}$, Fig. 7a). Sulfate reduction rates ranged from 16.95 to $27.71 \mathrm{nmol} \mathrm{cm}^{-3} \mathrm{~d}^{-1}$ in the upper sediment (0-6 cm depth) and decreased to $7.96 \mathrm{nmol} \mathrm{cm}^{-3} \mathrm{~d}^{-1}$ at the bottom, which corresponded to a simultaneous decrease in sulfate at the bottom of the core (Fig. 6a). Areal rates integrated over the entire sediment depth $(14 \mathrm{~cm})$ were 0.042 and $2.494 \mathrm{mmol} \mathrm{m}^{-2} \mathrm{~d}^{-1}$ for AOM and sulfate reduction, respectively.

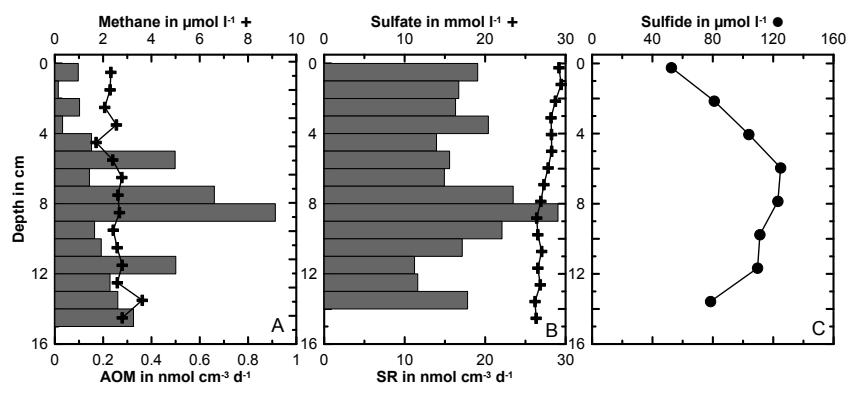

Figure 6. Solute concentrations and turnover rates in the new highflow regime core (NHFC) after experiment termination (358 d of runtime). Porewater profiles of methane (a, crosses), sulfate (b, crosses), sulfide (c, circles), and results of the radiotracer measurements for AOM (a, bars) and sulfate reduction (b, bars) are shown.

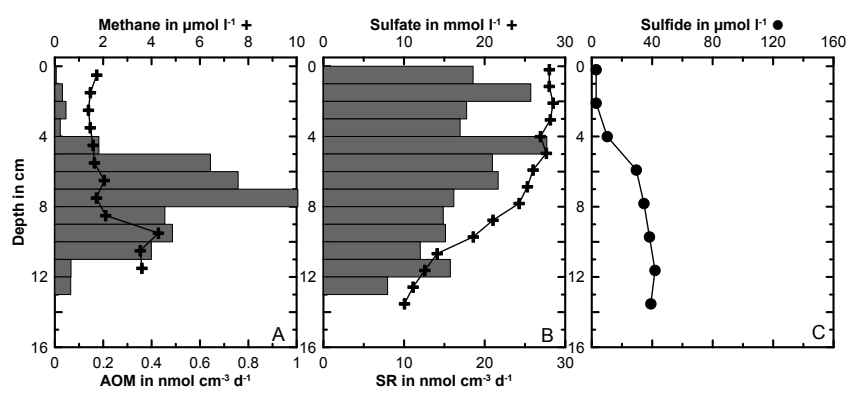

Figure 7. Solute concentrations and turnover rates in the new low flow core (NLFC) after experiment termination (358 d of runtime). Porewater profiles of methane (a, crosses), sulfate (b, crosses), and sulfide (c, circles) as well as results of the radiotracer measurements for AOM (a, bars) and sulfate reduction (b, bars) are shown.

The TC contents were similar in both the NHFC and NLFC and varied between 4.97 and 6.05 dry wt. \% (Fig. 8a, Fig. 9a). A carbon peak (6.05 dry wt. $\%, 7 \mathrm{~cm}$ sediment depth) resulted from higher TIC (3.09-3.16 dry wt. \%) in both cores. TOC (2.90-3.62 dry wt. \%) of the NHFC and NLFC did not differ considerably from ex situ data (2.913.40 dry wt. \%). Atomic C / N ratios were higher in both flow-through cores (8.67-9.43) compared to ex situ values (7.61-8.88), while TS was slightly lower $(0.82-1.18$ compared to $0.94-1.27$ dry wt. \%), especially in the upper region $(0-2 \mathrm{~cm})$ of the NHFC (0.84 compared to 1.11 dry wt. \%) and showed, in contrast to the ex situ cores, no minimum at $4.5 \mathrm{~cm}$ sediment depth (Figs. $8 \mathrm{c}$ and $9 \mathrm{c}$ ).

\section{Discussion}

\subsection{The impact of fluid seepage and related processes on porewater gradients}

Quepos Slide sediment cores that were studied ex situ showed a SMTZ and AOM peaks within the upper $20 \mathrm{~cm}$ of the sediment (Fig. 2). We are therefore confident that 


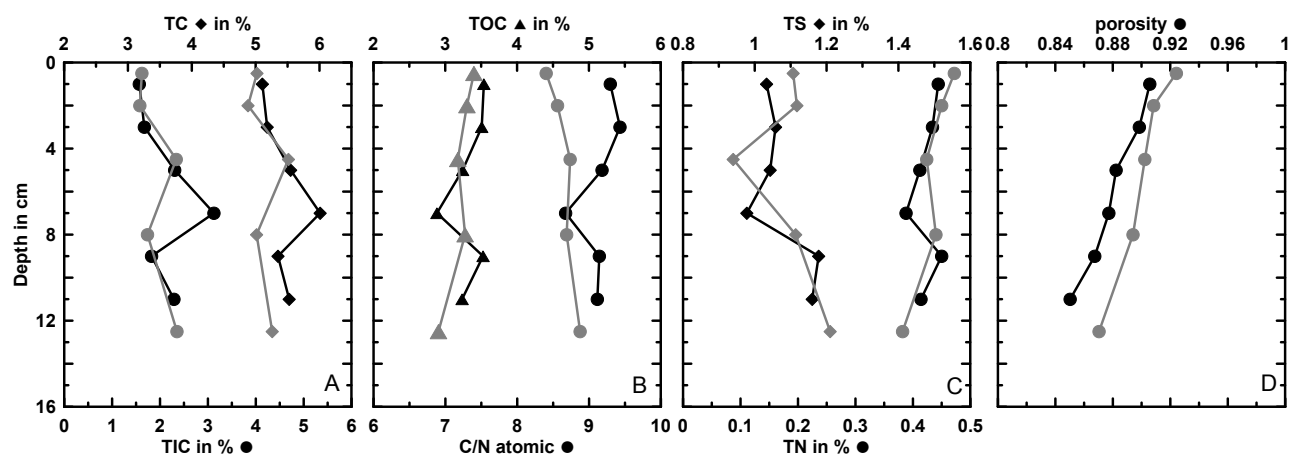

Figure 8. Sediment solid-phase parameters measured in the sediment of the ex situ replicate SO206-31 (MUC) core (grey lines and symbols) compared to the NHFC (originally LFC, black lines and symbols). Total carbon content (TC, diamonds) and total inorganic carbon content (TIC, circles) in dry wt. \% (a), atomic $\mathrm{C} / \mathrm{N}$ ratio (circle) and total organic carbon content (TOC, triangles) in dry wt. \% (b), total nitrogen (TN, diamonds) and total sulfur (TS, circles) in dry wt. \% (c), and porosity of the sediment (d).

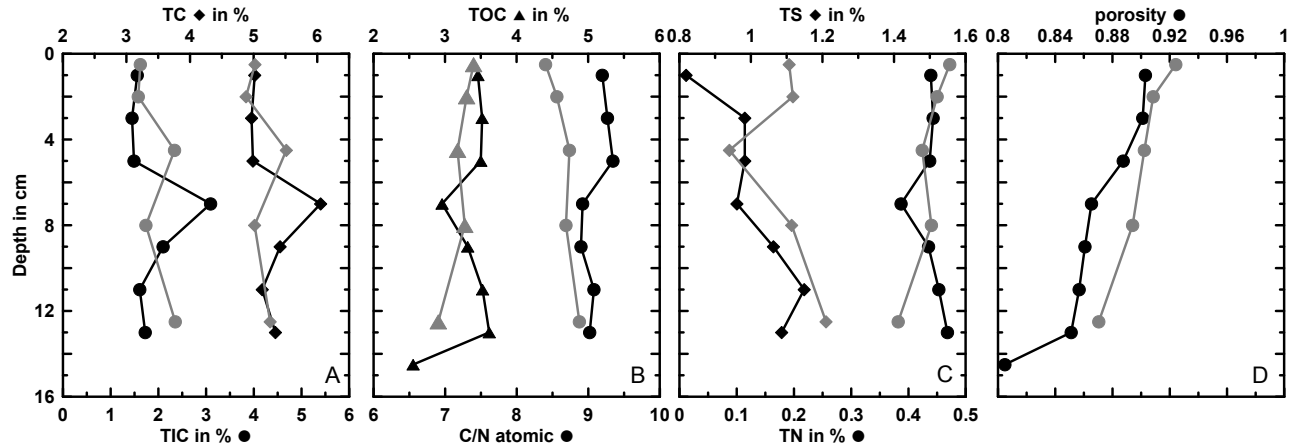

Figure 9. Sediment solid-phase parameters measured in the sediment of the ex situ replicate of the SO206-31 (MUC) core (grey lines and symbols) compared to the NLFC (original HFC, black lines and symbols). Total carbon content (TC, diamonds) and total inorganic carbon content (TIC, circle) in dry wt. \% (a), atomic C / $\mathrm{N}$ ratio (circle) and total organic carbon content (TOC, triangles) in dry wt. \% (b), total nitrogen (TN, diamonds) and total sulfur (TS, circles) in dry wt. \% (c), and porosity of the sediment (d)

the SLOT experiments (core length $14-16 \mathrm{~cm}$ ) contained the most active zone of the benthic methane filter. During the experiments, the depth of the SBTZ, as proxy for the SMTZ, was controlled by fluid flow and migrated over time. Fluid flow velocity in the low-flow regime core (LFC, $10.6 \mathrm{~cm} \mathrm{yr}^{-1}$ ) was in the same range of fluid flow modeled from the ex situ data $\left(5-29 \mathrm{~cm} \mathrm{yr}^{-1}\right)$. In the high-flow regime core (HFC, $106 \mathrm{~cm} \mathrm{yr}^{-1}$ ), the fluid flow was 2 to 10 times higher compared to our modeled data and also higher than other values published for Quepos Slide $\left(1-40 \mathrm{~cm} \mathrm{yr}^{-1}\right.$, Table 5; Karaca et al., 2012); however, the flow was still in the range of neighboring seeps $\left(0.1-200 \mathrm{~cm} \mathrm{yr}^{-1}\right.$; Hensen et al., 2004; Linke et al., 2005; Karaca et al., 2010; Krause et al., 2014). During the entire LFC/NHFC experiment no SBTZ developed, and consequently no steady state was reached. The missing evolution of a SBTZ was probably the result of a high hydrological residence time of the seepage medium ( $696 \mathrm{~d}$ for the LFC and $69 \mathrm{~d}$ for the NHFC), which in this case means the average time for the fluid to pass the water volume below the core and the entire sediment core. Nevertheless, small amounts of the seepage fluid obviously passed through the entire sediment, probably facilitated through channeling (Torres et al., 2002; Wankel et al., 2012), as demonstrated by the presence of methane in the outflow (Fig. 5) and bromide in the supernatant (Fig. 3g). The fraction of seepage medium (calculated from $\mathrm{Br}^{-}$concentration) emitted, relative to the total inflow seepage volume of the LFC, increased from 0 to $2.5 \%$ in the last phase $(260 \mathrm{~d})$ and further increased to $4 \%$ after the system was changed to high flow (NHFC). Low AOM activity was detected over the entire core after experiment termination, with highest turnover between 7 and $9 \mathrm{~cm}$ sediment depth, while methane concentrations stayed continuously low around $2-3 \mu \mathrm{mol} \mathrm{L} \mathrm{L}^{-1}$ over the entire core (see sampling artifacts, Sect. 3.2.3.). In the HFC experiment, the SBTZ and related AOM activity was much more pronounced than in the LFC. The SBTZ moved upwards from $14 \mathrm{~cm}$ (max. depth) to $<6 \mathrm{~cm}$ and dropped down to $10 \mathrm{~cm}$ sediment depth during the subsequent low-flow phase (NLFC). During the first phase, fluids and SBTZ showed continuous migration, which was fast initially and became slower towards the end. The relatively stable depth of the SBTZ at the end of the first experimental phase $(0-260 \mathrm{~d})$ indicated the transi- 
tion to a quasi-steady-state situation. Highest AOM rates, determined by radiotracer measurements after experiment termination, were found within this SBTZ $(6-10 \mathrm{~cm}$ sediment depth).

Sulfide concentrations of the HFC were generally highest within the SBTZ. In the LFC experiment, sulfide peaks were relatively broad and not very distinct, which was probably the result of a broad dispersive mixing layer between seepage and seawater medium. Due to the low fluid flow, higher sulfide concentrations evolved in the LFC as compared to the HFC, where sulfide was probably flushed out before it accumulated. Relatively low sulfide concentrations were also observed at Mound 11, a seep site with high AOM and sulfate reduction activity and high fluid flow (Hensen et al., 2004; Krause et al., 2014). In the LFC experiments, sulfide concentrations fluctuated over time. While the increase in sulfide concentration was most likely correlated with enhanced sulfate reduction, a decrease could be caused by the precipitation of metal sulfides and/or by microbial oxidation of sulfide (chemosynthesis). Precipitation of metal sulfides is correlated with a drop in pH (Glud et al., 2007; Preisler et al., 2007), as was observed in our study. Oxygen and nitrate are important electron acceptors for microbial oxidation of sulfide in seep habitats. However, free oxygen was probably available only temporally (if at all) in the overlying water of the core due to a sampling artifact (see results), which was in accordance with a redox potential of less than $300 \mathrm{mV}$ (Schulz, 2000). Moreover, sulfide oxidation with oxygen would create a drop in $\mathrm{pH}$. Conversely, $\mathrm{pH}$ increased in the surface sediment, which could be caused by sulfide oxidation via dissimilatory nitrate reduction to ammonium. The process has been previously observed at the sediment-water interface of a seep system (de Beer et al., 2006). Nitrate availability in the seawater medium was limited $\left(\sim 4 \mu \mathrm{mol} \mathrm{L}^{-1}\right)$. Nevertheless, sulfide-oxidizing bacteria such as Beggiatoa or Thioploca can accumulate nitrate in their vacuoles (Fossing et al., 1995; Preisler et al., 2007). Furthermore, sediment cores recovered from the field were covered by sulfide-oxidizing bacterial mats. Since oxygen concentration in the bottom water was extremely low in this OMZ ( $<22 \mu \mathrm{mol} \mathrm{L}^{-1}$; Wyrtki, 1962; Levin, 2003), nitrate appears to be the most attractive electron acceptor for these sulfide oxidizers.

In summary, the observed increase in sulfide concentrations was most likely attributed to sulfate reduction activity, according to the development of the SBTZ. A loss of sulfide was caused by porewater flushing through advection, which was most pronounced in the HFC. Sulfide loss via oxidation with nitrate (top of the sediment) and sulfide precipitation (below $2 \mathrm{~cm}$ sediment depth) occurred more likely in the LFC.

\subsection{Microbial turnover rates and efficiency of the benthic methane filter}

Table 5 provides an overview of parameters (fluid flow, methane emission, methane flux, AOM rate) from different methane seep locations. Integrated areal AOM rates $\left(45.15 \pm 11.48 \mathrm{mmol} \mathrm{m}^{-2} \mathrm{~d}^{-1}\right)$ of ex situ radiotracer measurements from the present study were in the upper range of previous modeled data $\left(1.5-42.1 \mathrm{mmol} \mathrm{m}^{-2} \mathrm{~d}^{-1}\right.$; Karaca et al., 2012) and moderate to high compared to other seep systems (Treude et al., 2003; Joye et al., 2004; Niemann et al., 2006; Knittel and Boetius, 2009; Krause et al., 2014). In the SLOT experiments, the calculated methane flux $\left(0.3-2.8 \mathrm{mmol} \mathrm{m}^{-2} \mathrm{~d}^{-1}\right)$ was lower compared to modeled flux $\left(9.1-41.7 \mathrm{mmol} \mathrm{m}^{-2} \mathrm{~d}^{-1}\right)$ of the replicate core and at the lower limit of the previously modeled data $(0.2$ $56.1 \mathrm{mmol} \mathrm{m}^{-2} \mathrm{~d}^{-1}$; Karaca et al., 2012). However, fluxes of the SLOT experiment were still in the range of data published for seeps in this region (Mau et al., 2006; Karaca et al., 2010). In agreement with the relatively low methane flux during the SLOT experiment, AOM rates (determined from the difference in methane concentration between in and outflow) were 1 to 2 orders of magnitude lower compared to ex situ determinations. AOM rates determined with radiotracer measurements after experiment termination revealed peaks within the SBTZ (proxy for the SMTZ) of the HFC (4-10 cmbsf). A broader distribution of AOM was found in the LFC, while similar integrated rates suggest the same potential for AOM. This agreement of integrated AOM rates despite differences in fluid flux illustrates a widening of the AOM zone with lower fluid fluxes, while a narrow AOM zone at high fluxes appears to be compensated by higher methane turnover. This effect was also reflected in a more distinct peak of sulfide (see above) and confirmed by simulations in the numerical model, specifically at the two model runs from SO206-31 (MUC) (Figs. 1 and 2). However, it should be kept in mind that methane concentrations during the experiment were much lower than under in situ pressure and it is therefore difficult to predict the upper limit of the balance between fluid flux and AOM activity.

While in a previous study the methane consumption efficiency of the benthic filter was estimated to range between 23 and $96 \%$ of the dissolved methane flux (Karaca et al., 2012), the efficiency in our study was between 92 and $100 \%$ in the modeled ex situ data and $99 \%$ for the SLOT setup. The latter value is based on the assumption that steady-state conditions were reached in the SLOT cores directly before fluid flow change, which was most likely reached in the HFC but not in the LFC (see discussion above). A reason for the partial disagreement in efficiency of the benthic filter compared to the earlier studies could be the natural variability in methane fluxes in this highly heterogeneous area. While Karaca et al. (2012) based their results on a large number of sediment cores (20 cores from the same seep site), only two randomly chosen sites were sampled in our study, and 


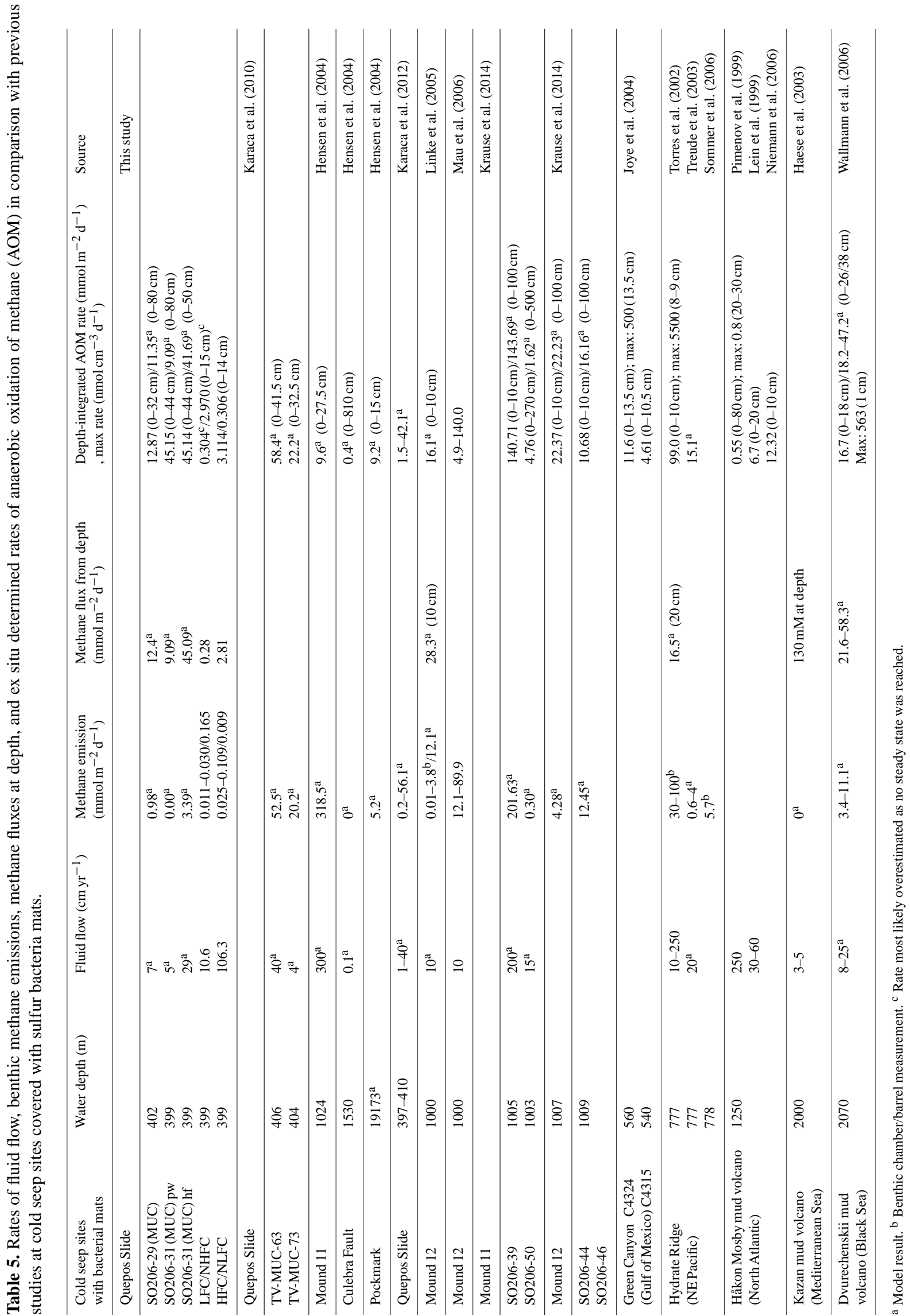


only one was used for the experiment. Another explanation could be temporal variability in fluid and methane flux. Karaca et al. (2012) conducted their study 10 years prior to ours. Methane flux as well as microbial activity could have changed easily over this period (Mau et al., 2007; Füri et al., 2010). A drop in methane flux would probably enhance the efficiency of the benthic methane filter. For example, in the present experiment, methane fluxes were 2 to 33 times lower compared to the model of Karaca et al. (2012) since the system was not pressurized and hence the solubility of methane was limited. Lower methane fluxes resulted in a high efficiency of the benthic microbial methane filter, despite relatively high fluid advection.

Radiotracer determination of microbial turnover rates after the experiment revealed sulfate reduction activity at levels higher than AOM, which was probably partly coupled to organic matter degradation. Since the cores were obtained within an oxygen minimum zone, sulfate reduction is supposedly the most important pathway for organic matter degradation (Jørgensen, 1977; Sørensen et al., 1979; Bohlen et al., 2011). High C / N ratios in cores of the terminated experiment compared to ex situ cores (Fig. 8 and 9) support this assumption, because advanced microbial degradation of fresh organic matter with high nitrogen content leads to a shift from low to high $\mathrm{C} / \mathrm{N}$ ratios (Whiticar, 2002). We assume that at most $80 \%$ of the sulfate reduction in the ex situ analyses of SO206-St31 (MUC) can be related to organic matter degradation $(\mathrm{AOM}: \mathrm{SR}=0.21)$. Most likely, this ratio was less, because ex situ radiotracer incubations were conducted under atmospheric pressure and less methane was available compared to the in situ conditions. However, because organoclastic sulfate reduction occurred ex situ at the sediment-water interface ( $0-2 \mathrm{cmbsf}$, Figs. 1 and 2), where the consumed sulfate is replenished relatively rapidly by diffusion and mixing from the seawater, this surface activity has probably only little effect on sulfate gradients deeper in the sediment (Jørgensen et al., 2001; Karaca et al., 2012).

In summary, the benthic microbial methane filter at Quepos Slide was found to be very efficient under continuous flow. Only increases in fluid and methane flux, such as that at the beginning of the experiment or the more pronounced one after the fluid flow change, led to a drop in efficiency. Once a new steady-state situation establishes, higher fluxes are expected to be compensated for by a more intensive AOM zone (see above).

\subsection{Response time of the microbial benthic methane filter}

In the outflow of the LFC, methane concentrations increased only little and decreased after $202 \mathrm{~d}$ (directly before fluid flow change) to the initial concentration. In contrast, methane concentrations in the outflow of the HFC were high $\left(7.5 \mu \mathrm{mol} \mathrm{L}{ }^{-1}\right)$ at the beginning $(29 \mathrm{~d})$ and decreased quasi-exponentially to concentrations of $\sim 2 \mu \mathrm{mol} \mathrm{L}^{-1}$ af- ter $171 \mathrm{~d}$. In the same time interval, the fraction of the methane-containing "seepage" medium at the sedimentwater interface, calculated from the tracer (bromide) concentrations, changed from 13 to $34 \%$ (Fig. 4a, j). From the delivered methane (125.5 and $\left.376.4 \mu \mathrm{mol} \mathrm{L}^{-1}\right), 30$ and $98 \%$ were oxidized after 29 and $171 \mathrm{~d}$, respectively, in the HFC. This period $(0-171 \mathrm{~d})$ can be interpreted as the response time of the benthic microbial methane filter in the sediments of Quepos Slide. After the change in the flow regime, the efflux of methane suddenly reduced to only $22 \%\left(0.009 \mathrm{mmol} \mathrm{m}^{-2} \mathrm{~d}^{-1}\right)$ in the former HFC (i.e., NLFC), while the efflux in the former LFC (i.e., NHFC) increased rapidly 15 -fold $\left(0.169 \mathrm{mmol} \mathrm{m}^{-2} \mathrm{~d}^{-1}\right)$ after changing the fluid flow. Based on bromide concentrations, the fraction of seepage medium in the outflow of the NHFC was $4 \%$, which should theoretically equal $38.5 \mu \mathrm{mol} \mathrm{L}^{-1}$ methane in the outflow if no methane were consumed. Compared to methane concentrations directly measured in the outflow, only $~ 70 \%$ of the inflow methane was oxidized and $30 \%$ was emitted.

These results illustrate how sudden events could result in an abrupt increase in methane efflux. Mau et al. (2006) attributed fluctuations in methane concentrations in the water column, which occurred between autumn 2002 and 2003 at the Costa Rican seeps, to an earthquake in June 2002. However, it was not specified whether the increased methane flux resulted from increased fluid flow or simply bubble release; neither was specified whether it was a continuous increase in methane flux or just a transient effect.

The experiments of the present study clearly show that the benthic microbial methane filter is able to respond within a relatively brief time of 5-6 months to increased methane fluxes and leads to the development of a much shallower and thinner AOM zone. Even if methane fluxes and methane concentrations were 4 times higher in situ, as expected from modeled methane fluxes of this study, the benthic microbial methane filter may still be able to respond quickly if a methanotrophic community is already fully established. Outside of seep habitats, where the microbial benthic methane filter is either absent or in deeper sediment zones, the adaptation might require much more time, since the doubling rate of the microbes involved is on the order of a few months (Girguis et al., 2005; Nauhaus et al., 2007; Krüger et al., 2008; Meulepas et al., 2009). Mau et al. (2007) observed a reduction in methane emissions in the water column above the earthquake-impacted seepage area by $50-90 \%$ in a period of 1 year. In our experiments, the benthic microbial methane filter required only $\sim 170 \mathrm{~d}$ to adapt to the new flow regime. It is not clear whether the subsequent reduction in methane emissions observed by Mau et al. (2007) was the result of an ephemeral pulse of methane flux or the adaption of the microbial benthic methane filter. Our results indicate that both situations are conceivable.

Another scenario, in which the benthic methane filter would be challenged, is the destabilization of gas hydrates as a result of climate change (Buffett and Archer, 2004). 
However, due to retarded heat flux into deeper sediment layers, dissociation of considerable gas hydrate volumes probably require hundreds to thousands of years (Biastoch et al., 2011). In the present study, we demonstrate that an established microbial benthic methane filter can compensate for relatively abrupt increases in methane flux. Only "pristine" sediments which are virtually devoid of methanotrophs are expected to show long adaptation periods of up to several years or even decades (Dale et al., 2008) due to slow growth rates of the anaerobes (Girguis et al., 2005; Nauhaus et al., 2007; Goffredi et al., 2008).

\section{Conclusions}

Surface sediments of the Quepos Slide, a cold seep on the Pacific coastline of Costa Rica located within the eastern tropical North Pacific oxygen minimum zone, feature a very efficient benthic methane filter, demonstrated by direct measurements of methane turnover rates ex situ and numerical reaction modeling. In vitro experiments with intact sediment cores using a sediment-flow-through system further allowed for following the adaptation of the SMTZ to changes in fluid flow, which revealed that the SMTZ narrows to a thin layer under high fluid flow conditions. Methane (ca. $1 \mathrm{mmol} \mathrm{L}^{-1}$ at atmospheric pressure) transported under high fluid flow was efficiently consumed ( $99 \%$ oxidation) by the benthic methane filter after a response period of ca. $170 \mathrm{~d}$. These results illustrate how an established benthic methanotrophic microbial community could react to pulses in fluid and methane flow induced, for example, by earthquakes or gas hydrate dissociation, and how it regains its efficiency level after passing through a non-steady-state period. As we present here only one example of a response to a sudden fluid flow pulse, further studies from other seep systems are advisable to validate our results.

Author contributions. T. Treude, P. Linke, and C. Hensen initiated this study. P. Steeb, S. Krause, M. Nuzzo, and A. W. Dale sampled the sediment. S. Krause and P. Steeb performed the radiotracer incubations. Onboard, A. W. Dale was responsible for porewater measurements and M. Nuzzo conducted the methane measurements. C. Hensen and P. Steeb carried out the numerical modeling with input from A. W. Dale. S. Krause and P. Steeb carried out rate measurements and turnover calculations. Experiments were designed by T. Treude and P. Linke. Experiments were performed by P. Steeb, including measurements and calculations. P. Steeb wrote the manuscript with input from all co-authors.

Acknowledgements. We thank the captain and the crew of $\mathrm{R} / \mathrm{V}$ SONNE and all staff members who supported this work onboard. Special thanks go to B. Domeyer, A. Bleyer, R. Ebbinghaus, R. Surberg, E. Corrales-Cordero, and E. Pinero for technical support during porewater analyses. K. Kretschmer is thanked for help during maintenance of the SLOT system. K. Kretchmer, J. Farkas, and J. Hommer are thanked for technical support during radiotracer analyses. We thank the three anonymous referees and P. Dando for their helpful comments on the submitted manuscript. This project was financed through Collaborative Research Center (SFB) 574 "Volatiles and Fluids in Subduction Zones" and the Cluster of Excellence "The Future Ocean" funded by the German Research Foundation (DFG). M. Nuzzo was funded by the Portuguese Science and Technology Foundation through post-doctoral fellowship FCT-SFRH/BPD/44598/2008.

The article processing charges for this open-access publication were covered by a Research Centre of the Helmholtz Association.

Edited by: C. P. Slomp

\section{References}

Aiello, I. W.: Fossil seep structures of the Monterey Bay region and tectonic/structural controls on fluid flow in an active transform margin, Palaeogeogr. Palaeocl., 227, 124-142, 2005.

Beal, E. J., House, C. H., and Orphan, V. J.: Manganese- and irondependent marine methane oxidation, Science, 325, 184-187, 2009.

Biastoch, A., Treude, T., Rüpke, L. H., Riebesell, U., Roth, C., Burwicz, E. B., Park, W., Latif, M., Böning, C. W., Madec, G., and Wallmann, K.: Rising Arctic Ocean temperatures cause gas hydrate destabilization and ocean acidification, Geophys. Res. Lett., 38, 1-5, 2011.

Boetius, A., Ravenschlag, K., Schubert, C. J., Rickert, D., Widdel, F., Gieseke, A., Amann, R., Jørgensen, B. B., Witte, U., Pfannkuche, O., and Jorgensen, B. B.: A marine microbial consortium apparently mediating anaerobic oxidation of methane, Nature, 407, 623-626, 2000.

Bohlen, L., Dale, A. W., Sommer, S., Mosch, T., Hensen, C., Noffke, A., Scholz, F., and Wallmann, K.: Benthic nitrogen cycling traversing the Peruvian oxygen minimum zone, Geochim. Cosmochim. Ac., 75, 6094-6111, 2011.

Bohrmann, G., Heeschen, K., Jung, C., Weinrebe, W., Baranov, B., Heath, R., Hu, V., Hort, M., and Masson, D.: Widespread fluid expulsion along the seafloor of the Costa Rica convergent margin, Terra Nova, 14, 69-79, 2002.

Borowski, W. S., Paull, C. K., and Ussler III, W.: Marine pore-water sulfate profiles indicate in situ methane flux from underlying gas hydrate, Geology, 24, 655-658, 1996.

Borowski, W. S., Paull, C. K., and Ussler III, W.: Global and local variations of interstitial sulfate gradients in deep-water, continental margin sediments: Sensitivity to underlying methane and gas hydrates. Mar. Geol. 159, 131-154. 1999.

Buffett, B. and Archer, D.: Global inventory of methane clathrate: sensitivity to changes in the deep ocean, Earth Planet. Sc. Lett. 227, 185-199, 2004.

Cline, J.: Spectrophotometric determination of hydrogen sulfide in natural waters, Limnol. Oceanogr., 14, 454-458, 1969.

Crutchley, G. J., Klaeschen, D., Planert, L., Bialas, J., Berndt, C., Papenberg, C., Hensen, C., Hornbach, M. J., Krastel, S., and Brueckmann, W.: The impact of fluid advection on gas hydrate 
stability: Investigations at sites of methane seepage offshore Costa Rica, Earth Planet. Sc. Lett., 401, 95-109, 2014.

Dale, A. W., Van Cappellen, P., Aguilera, D. R., and Regnier, P.: Methane efflux from marine sediments in passive and active margins: Estimations from bioenergetic reaction-transport simulations, Earth Planet. Sc. Lett., 265, 329-344, 2008.

Dale, A. W., Brüchert, V., Alperin, M., and Regnier, P.: An integrated sulfur isotope model for Namibian shelf sediments, Geochim. Cosmochim. Ac., 73, 1924-1944, 2009.

Dalsgaard, T., Nielsen, L. P., Brotas, V., Viaroli, P., Underwood, G., Nedwell, D., Sundbäck, K., Rysgaard, S., Miles, A., Bartoli, M., Dong, L., Thornton, D. C. O., Ottosen, L. D. M., Castaldelli, G., and Risgaard-Petersen, N.: Sediment Characteristics, in: Protocol Handbook for NICE- Nitrogen Cycling in Esturies: a project under EU research programme: Marine Science and Technology (MAST III), National Environmental Research Institute, Arhus, Denmark, 53-54, 2000.

De Beer, D., Sauter, E., Niemann, H., Kaul, N., Witte, U., Schlüter, M., and Boetius, A.: In situ fluxes and zonation of microbial activity in surface sediments of the Håkon Mosby Mud Volcano, Limnol. Oceanogr., 51, 1315-1331, 2006.

Ettwig, K. F., Butler, M. K., Le Paslier, D., Pelletier, E., Mangenot, S., Kuypers, M. M. M., Schreiber, F., Dutilh, B. E., Zedelius, J., de Beer, D., Gloerich, J., Wessels, H. J. C. T., van Alen, T., Luesken, F., Wu, M. L., van de Pas-Schoonen, K. T., Op den Camp, H. J. M., Janssen-Megens, E. M., Francoijs, K.-J., Stunnenberg, H., Weissenbach, J., Jetten, M. S. M., and Strous, M.: Nitrite-driven anaerobic methane oxidation by oxygenic bacteria, Nature, 464, 543-548, 2010.

Fischer, D., Sahling, H., and Nöthen, K.: Interaction between hydrocarbon seepage, chemosynthetic communities, and bottom water redox at cold seeps of the Makran accretionary prism: insights from habitat-specific pore water sampling and modeling, Biogeochemistry, 9, 2013-2031, 2012.

Fischer, D., Mogollón, J. M., Strasser, M., Pape, T., Bohrmann, G., Fekete, N., Spiess, V., and Kasten, S.: Subduction zone earthquake as potential trigger of submarine hydrocarbon seepage, Nat. Geosci., 6, 647-651, 2013.

Fossing, H., Gallardo, V., Jørgensen, B., Hüttel, M., Nielson, L. P., Schulz, H., Canfield, D. E., Forster, S., Glud, R. N., Gundersen, J. K., Küver, J., Ramsing, N. B., Teske, A., Thamdrup, B., and Ulloa, O.: Concentration and transport of nitrate by the mat-forming sulphur bacterium Thioploca, Nature, 374, 714715,1995

Füri, E., Hilton, D. R., Tryon, M. D., Brown, K. M., McMurtry, G. M., Brückmann, W., and Wheat, C. G.: Carbon release from submarine seeps at the Costa Rica fore arc: Implications for the volatile cycle at the Central America convergent margin, Geochem. Geophy. Geosy., 11, doi:10.1029/2009GC002810, 2010

Girguis, P., Cozen, A., and DeLong, E.: Growth and population dynamics of anaerobic methane-oxidizing archaea and sulfatereducing bacteria in a continuous-flow bioreactor, Appl. Environ. Microb., 71, 3725-3733, 2005.

Glud, R. N., Berg, P., Fossing, H., and Jørgensen, B. B.: Effect of the diffusive boundary layer on benthic mineralization and $\mathrm{O}_{2}$ distribution: A theoretical model analysis, Limnol. Oceanogr., 52, 547-557, 2007.
Goffredi, S. K., Wilpiszeski, R., Lee, R., and Orphan, V. J.: Temporal evolution of methane cycling and phylogenetic diversity of archaea in sediments from a deep-sea whale-fall in Monterey Canyon, California, ISME J., 2, 204-220, 2008.

Haese, R. R., Meile, C., Cappellen, P. V., and De Lange, G. J.: Carbon geochemistry of cold seeps: methane fluxes and transformation in sediments from Kazan mud volcano, eastern Mediterranean Sea, Earth Planet. Sc. Lett., 212, 361-375, 2003.

Han, X., Suess, E., Sahling, H., and Wallmann, K.: Fluid venting activity on the Costa Rica margin: new results from authigenic carbonates, Int. J. Earth Sci., 93, 596-611, 2004.

Harders, R., Ranero, C. R., Weinrebe, W., and Behrmann, J. H.: Submarine slope failures along the convergent continental margin of the Middle America Trench, Geochem. Geophy. Geosy., 12, doi:10.1029/2010GC003401, 2011.

Henrys, S., Reyners, M., Pecher, I., Bannister, S., Nishimura, Y., and Maslen, G.: Kinking of the subducting slab by escalator normal faulting beneath the North Island of New Zealand, Geology, 34, 777-780, 2006.

Hensen, C., and Wallmann, K.: Methane formation at Costa Rica continental margin-constraints for gas hydrate inventories and cross-décollement fluid flow, Earth Planet. Sc. Lett., 236, 41-60, 2005.

Hensen, C., Wallmann, K., Schmidt, M., Ranero, C. R., and Suess, E.: Fluid expulsion related to mud extrusion off Costa Rica - A window to the subducting slab, Geology, 32, 201-204, 2004.

Hesse, R., Frape, S. K., Egeberg, P. K., and Matsumoto, R.: Stable Isotope Studies $(\mathrm{Cl}, \mathrm{O}$, and $\mathrm{H})$ of Interstitial Waters from Site 997, Blake Ridge Gas Hydrate Field, West Atlantic. Proc. Ocean Drill. Program, Sci. results, 164, 129-137, 2000.

Hinrichs, K., and Boetius, A.: The anaerobic oxidation of methane: new insights in microbial ecology and biogeochemistry, in: Ocean Margin Systems, edited by: Wefer, G., Billet, D., Hebbeln, D., Jørgensen, B., Schlüter, M., and Van Weering, T., SpringerVerlag, Berlin, Heidelberg, 457-477, 2002.

Ivanenkov, V. N. and Lyakhin, Y. I.: Determination of total alkalinity in seawater, in: Methods of Hydrochemical Investigations in the Ocean, edited by: Bordovsky, O. K. and Ivanenkov, V. N., Nauka Publ. House, Moscow, Russia, 110-114, 1978.

Jørgensen, B. B.: The Sulfur Cycle of a Coastal Marine Sediment (Limfjorden, Denmark), Limnol. Oceanogr., 22, 814-832, 1977.

Jørgensen, B. B.: A comparison of methods for the quantification of bacterial sulfate reduction in coastal marine sediments. 1. Measurements with radiotracer techniques, Geomicrobiol. J., 1, 1127, 1978.

Jørgensen, B., Weber, A., and Zopfi, J.: Sulfate reduction and anaerobic methane oxidation in Black Sea sediments, Deep-Sea Res. Pt. I, 48, 2097-2120, 2001.

Joye, S. B., Boetius, A., Orcutt, B. N., Montoya, J. P., Schulz, H. N., Erickson, M. J., and Lugo, S. K.: The anaerobic oxidation of methane and sulfate reduction in sediments from Gulf of Mexico cold seeps, Chem. Geol., 205, 219-238, 2004.

Judd, A., Hovland, M., and Dimitrov, L.: The geological methane budget at continental margins and its influence on climate change, Geofluids, 2, 109-126, 2002.

Kallmeyer, J., Ferdelman, T. G., Weber, A., Fossing, H., and Jørgensen, B. B.: A cold chromium distillation procedure for radiolabeled sulfide applied to sulfate reduction measurements, Limnol. Oceanogr-Meth., 2, 171-180, 2004. 
Karaca, D., Hensen, C., and Wallmann, K.: Controls on authigenic carbonate precipitation at cold seeps along the convergent margin off Costa Rica, Geochem. Geophy. Geosy., 11, 1-19, 2010.

Karaca, D., Schleicher, T., Hensen, C., Linke, P., and Wallmann, K.: Quantification of methane emission from bacterial mat sites at Quepos Slide offshore Costa Rica, Int. J. Earth Sci., 1-25, 2012.

Kluesner, J. W., Silver, E. A., Bangs, N. L., McIntosh, K. D., Gibson, J., Orange, D., Ranero, C. R., and von Huene, R.: High density of structurally controlled, shallow to deep water fluid seep indicators imaged offshore Costa Rica, Geochem. Geophy. Geosy., 14, 519-539, 2013.

Knittel, K. and Boetius, A.: Anaerobic oxidation of methane: progress with an unknown process, Annu. Rev. Microbiol., 63, 311-334, 2009.

Krause, S., Steeb, P., Hensen, C., Liebetrau, V., Dale, A. W., Nuzzo, M., and Treude, T.: Microbial activity and carbonate isotope signatures as a tool for identification of spatial differences in methane advection: a case study at the Pacific Costa Rican margin, Biogeosciences, 11, 507-523, doi:10.5194/bg-11-507-2014, 2014

Krüger, M., Blumenberg, M., Kasten, S., Wieland, A., Känel, L., Klock, J., Michaelis, W., and Seifert, R.: A novel, multi-layered methanotrophic microbial mat system growing on the sediment of the Black Sea, Environ. Microbiol., 10, 1934-1947, 2008.

Kutterolf, S., Liebetrau, V., Mörz, T., Freundt, A., Hammerich, T., and Garbe-Schönberg, D.: Lifetime and cyclicity of fluid venting at forearc mound structures determined by tephrostratigraphy and radiometric dating of authigenic carbonates, Geology, 36, 707-710, 2008.

Kvenvolden, K.: Methane hydrate in the global organic carbon cycle, Terra Nova, 14, 302-306, 2002.

Lein, A., Vogt, P., Crane, K., Egorov, A., and Ivanov, M.: Chemical and isotopic evidence for the nature of the fluid in $\mathrm{CH}_{4}$ containing sediments of the Hakon Mosby Mud Volcano, Geo.Mar. Lett., 19, 76-83, 1999.

Levin, L. A.: Oxygen Minimum Zone Benthos?: Adaption and Community, Ocean. Mar. Biol. Annu. Rev., 41, 1-45, 2003.

Linke, P., Wallmann, K., Suess, E., Hensen, C., and Rehder, G.: In situ benthic fluxes from an intermittently active mud volcano at the Costa Rica convergent margin, Earth Planet. Sc. Lett., 235, 79-95, 2005.

Mau, S., Sahling, H., Rehder, G., Suess, E., Linke, P., and Soeding, E.: Estimates of methane output from mud extrusions at the erosive convergent margin off Costa Rica, Mar. Geol., 225, 129144, 2006.

Mau, S., Rehder, G., Arroyo, I. G., Gossler, J., and Suess, E.: Indications of a link between seismotectonics and $\mathrm{CH}_{4}$ release from seeps off Costa Rica. Geochem, Geophy. Geosy., 8, 1-13, 2007.

Mau, S., Rehder, G., Sahling, H., Schleicher, T., and Linke, P.: Seepage of methane at Jaco Scar, a slide caused by seamount subduction offshore Costa Rica, Int. J. Earth Sci., 103, 1801-1815, doi:10.1007/s00531-012-0822-z, 2012.

Meulepas, R. J. W., Jagersma, C. G., Gieteling, J., Buisman, C. J. N., Stams, A. J. M., and Lens, P. N. L.: Enrichment of anaerobic methanotrophs in sulfate-reducing membrane bioreactors, Biotechnol. Bioeng., 104, 458-470, 2009.

Milucka, J., Ferdelman, T. G., Polerecky, L., Franzke, D., Wegener, G., Schmid, M., Lieberwirth, I., Wagner, M., Widdel, F., and
Kuypers, M. M. M.: Zero-valent sulphur is a key intermediate in marine methane oxidation, Nature, 2, 1-23, 2012.

Minami, H., Tatsumi, K., Hachikubo, A., Yamashita, S., Sakagami, H., Takahashi, N., Shoji, H., Jin, Y. K., Obzhirov, A., Nikolaeva, N., and Derkachev, A.: Possible variation in methane flux caused by gas hydrate formation on the northeastern continental slope off Sakhalin Island, Russia, Geo-Marine Lett., 32, 525534, 2012.

Nauhaus, K., Albrecht, M., Elvert, M., Boetius, A., and Widdel, F.: In vitro cell growth of marine archaeal-bacterial consortia during anaerobic oxidation of methane with sulfate, Environ. Microbiol., 9, 187-196, 2007.

Niemann, H., Lösekann, T., de Beer, D., Elvert, M., Nadalig, T., Knittel, K., Amann, R., Sauter, E. J., Schlüter, M., Klages, M., Foucher, J. P., and Boetius, A.: Novel microbial communities of the Haakon Mosby mud volcano and their role as a methane sink, Nature, 443, 854-858, 2006.

Orcutt, B. N., Sylvan, J. B., Knab, N. J., and Edwards, K. J.: Microbial ecology of the dark ocean above, at, and below the seafloor, Microbiol. Mol. Biol. R., 75, 361-422, 2011.

Pimenov, N., Savvichev, A., Rusanov, I., Lein, A., Egorov, A., Gebruk, A., Moskalev, L., and Vogt, P.: Microbial processes of carbon cycle as the base of food chain of Hakon Mosby Mud Volcano benthic community, Geo.-Mar. Lett., 19, 89-96, 1999.

Preisler, A., de Beer, D., Lichtschlag, A., Lavik, G., Boetius, A., and Jørgensen, B. B.: Biological and chemical sulfide oxidation in a Beggiatoa inhabited marine sediment, ISME J., 1, 341-353, 2007.

Ranero, C. and von Huene, R.: Subduction erosion along the Middle America convergent margin, Nature, 404, 748-752, 2000.

Ranero, C. R., Grevemeyer, I., Sahling, H., Barckhausen, U., Hensen, C., Wallmann, K., Weinrebe, W., Vannucchi, P., von Huene, R., and McIntosh, K.: Hydrogeological system of erosional convergent margins and its influence on tectonics and interplate seismogenesis, Geochem. Geophy. Geosy., 9, doi:10.1029/2007GC001679, 2008.

Reeburgh, W. S.: Oceanic methane biogeochemistry, Chem. Rev., 107, 486-513, 2007.

Sahling, H., Rickert, D., Lee, R. W., Linke, P., and Suess, E.: Macrofaunal community structure and sulfide flux at gas hydrate deposits from the Cascadia convergent margin, NE Pacific, Mar. Ecol.-Prog. Ser., 231, 121-138, 2002.

Sahling, H., Masson, D. G., Ranero, C. R., Hühnerbach, V., Weinrebe, W., Klaucke, I., Bürk, D., Brückmann, W., and Suess, E.: Fluid seepage at the continental margin offshore Costa Rica and southern Nicaragua, Geochem. Geophy. Geosy., 9, 1-22, 2008.

Schmidt, M., Hensen, C., Mörz, T., Müller, C., Grevemeyer, I., Wallmann, K., Mau, S., and Kaul, N.: Methane hydrate accumulation in "Mound 11" mud volcano, Costa Rica forearc, Mar. Geol., 216, 83-100, 2005.

Schulz, H. D.: Redox Measurements in Marine Sediments, in: REDOX: Fundamentals, Processes, and Applications, edited by: Schüring, J., Schulz, H. D., Böttcher, J., and Duijnisveld, W. H M., Springer, Berlin, 235-246, 2000.

Sommer, S., Pfannkuche, O., Linke, P., Luff, R., Greinert, J., Drews, M., Gubsch, S., Pieper, M., Poser, M., and Viergutz, T.: Efficiency of the benthic filter: Biological control of the emission of dissolved methane from sediments hosting shallow gas hy- 
drates at Hydrate Ridge, Global Biogeochem. Cy., 20, GB2019, doi:10.1029/2004GB002389, 2006.

Sørensen, J., Jørgensen, B., and Revsbech, N.: A comparison of oxygen, nitrate, and sulfate respiration in coastal marine sediments, Microb. Ecol., 5, 105-115, 1979.

Steeb, P., Linke, P., and Treude, T.: A sediment flow-through system to study the impact of shifting fluid and methane flow regimes on the efficiency of the benthic methane filter, Limnol. Oceanogr.Meth., 12, 25-45, 2014.

Suess, E.: Marine Cold Seeps, in: Handbook of Hydrocarbon and Lipid Microbiology, edited by: Timmis, K. N., Springer, Berlin, Heidelberg, 188-198, 2010.

Syracuse, E. M. and Abers, G. A.:Global compilation of variations in slab depth beneath arc volcanoes and implications, Geochem. Geophy. Geosy., 7, 1-18, 2006.

Tishchenko, P., Hensen, C., Wallmann, K., and Wong, C. S.: Calculation of the stability and solubility of methane hydrate in seawater, Chem. Geol., 219, 37-52, 2005.

Torres, M. E., McManus, J., Hammond, D. E., de Angelis, M. A., Heeschen, K. U., Colbert, S. L., Tryon, M. D., Brown, K. M., and Suess, E.: Fluid and chemical fluxes in and out of sediments hosting methane hydrate deposits on Hydrate Ridge, OR, I: Hydrological provinces, Earth Planet. Sc. Lett., 201, 525-540, 2002.

Treude, T., Boetius, A., Knittel, K., Wallmann, K., and Barker Jørgensen, B.: Anaerobic oxidation of methane above gas hydrates at Hydrate Ridge, NE Pacific Ocean, Mar. Ecol.-Prog. Ser., 264, 1-14, 2003.

Treude, T., Krüger, M., Boetius, A., and Jørgensen, B.: Environmental control on anaerobic oxidation of methane in the gassy sediments of Eckernfoerde Bay (German Baltic), Limnol. Oceanogr., 50, 1771-1786, 2005.

Tryon, M. D., Brown, K. M., and Torres, M. E.: Fluid and chemical fluxes in and out of sediments hosting methane hydrate deposits on Hydrate Ridge, OR, II: Hydrological provinces, Earth Planet. Sc. Lett., 201, 541-557, 2002.
Tryon, M. D., Wheat, C. G., and Hilton, D. R.: Fluid sources and pathways of the Costa Rica erosional convergent margin, Geochem. Geophy. Geosy., 11, doi:10.1029/2009GC002818, 2010.

Visser, W., Scheffers, W. A., Batenburg-van der Vegte, W. H., and van Dijken, J. P.: Oxygen requirements of yeasts, Appl. Environ. Microb., 56, 3785-3792, 1990.

Wallmann, K., Drews, M., Aliosi, G., and Bohrmann, G.: Methane discharge into the Black Sea and the global ocean via fluid flow through submarine mud volcanoes, Earth Planet Sc. Lett., 248, 545-560, 2006.

Wallmann, K., Pinero, E., Burwicz, E., Haeckel, M., Hensen, C., Dale, A., and Ruepke, L.: The Global Inventory of Methane Hydrate in Marine Sediments: A Theoretical Approach, Energies, 5, 2449-2498, 2012.

Wankel, S. D., Adams, M. M., Johnston, D. T., Hansel, C. M., Joye, S. B., and Girguis, P. R.: Anaerobic methane oxidation in metalliferous hydrothermal sediments: influence on carbon flux and decoupling from sulfate reduction, Environ. Microbiol., 14, 2726-2740, 2012.

Whiticar, M. J.: Diagenetic relationships of methanogenesis , nutrients, acoustic turbidity, pockmarks and freshwater seepages in Eckernförde Bay, Mar. Geol., 182, 29-53, 2002.

Widdel, F. and Bak, F.: Gram-negative mesophilic sulfate-reducing bacteria, in: The Prokaryotes, edited by: Dworkin, M., Falkow, S., Rosenberg, E., Schleifer, K.-H., and Stackebrandt, E. Springer, USA, 3352-3378, 2006.

Wyrtki, K.: The oxygen minima in relation to ocean circulation, Deep-Sea Res., 9, 11-23, doi:10.1029/2009GC002818, 1962. 